\title{
Article \\ Acidified Biochar as a Soil Amendment to Drought Stressed (Vicia faba L.) Plants: Influences on Growth and Productivity, Nutrient Status, and Water Use Efficiency
}

\author{
Taia A. Abd El-Mageed 1,*D, Eman E. Belal ${ }^{1}$, Mohamed O. A. Rady ${ }^{2}$, Shimaa A. Abd El-Mageed ${ }^{2}$, \\ Elsayed Mansour ${ }^{3}(\mathbb{D})$, Mohamed F. Awad ${ }^{4}(\mathbb{D})$ and Wael M. Semida ${ }^{5}$ \\ 1 Soil and Water Department, Faculty of Agriculture, Fayoum University, Fayoum 63514, Egypt; \\ eeb00@fayoum.edu.eg \\ 2 Agronomy Department, Faculty of Agriculture, Fayoum University, Fayoum 63514, Egypt; \\ mer00@fayoum.edu.eg (M.O.A.R.); sa1944@fayoum.edu.eg (S.A.A.E.-M.) \\ 3 Agronomy Department, Faculty of Agriculture, Zagazig University, Zagazig 44519, Egypt; \\ sayed_mansour_84@yahoo.es \\ 4 Department of Biology, College of Science, Taif University, P.O. Box 11099, Taif 21944, Saudi Arabia; \\ m.fadl@tu.edu.sa \\ 5 Horticulture Department, Faculty of Agriculture, Fayoum University, Fayoum 63514, Egypt; \\ wms00@fayoum.edu.eg \\ * Correspondence: taa00@fayoum.edu.eg; Tel.: +20-1067536208; Fax: +20-84-6334964
}

\section{check for} updates

Citation: Abd El-Mageed, T.A.; Belal, E.E.; Rady, M.O.A.; Abd El-Mageed,

S.A.; Mansour, E.; Awad, M.F.;

Semida, W.M. Acidified Biochar as a Soil Amendment to Drought Stressed (Vicia faba L.) Plants: Influences on Growth and Productivity, Nutrient Status, and Water Use Efficiency. Agronomy 2021, 11, 1290. https:// doi.org/10.3390/agronomy11071290

Academic Editor: Pasquale Losciale

Received: 25 May 2021

Accepted: 21 June 2021

Published: 25 June 2021

Publisher's Note: MDPI stays neutral with regard to jurisdictional claims in published maps and institutional affiliations.

Copyright: (C) 2021 by the authors. Licensee MDPI, Basel, Switzerland. This article is an open access article distributed under the terms and conditions of the Creative Commons Attribution (CC BY) license (https:// creativecommons.org/licenses/by/ $4.0 /)$.

\begin{abstract}
Drought is one of the major threats to global food security. Biochar use in agriculture has received much attention and improving it through chemical modification offers a potential approach for enhancing crop productivity. There is still limited knowledge on how acidified biochar influences soil properties, and consequently its influences on the agricultural productivity of drought stressed plants. The water use efficiency (I-WUE) of drought stressed faba beans was investigated through the effects of acidified biochar (ACBio) (a 3:100 (w:w) combination of citric acid and biochar) on soil properties, growth, productivity, nutrient uptake, water productivity (WP), and irrigation. Two field

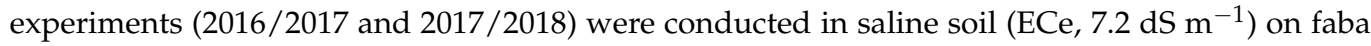
been plants grown under three irrigation regimes (i.e., 100,80 , and $60 \%$ of crop evapotranspiration (ETc)) combined with three levels of $\operatorname{ACBio~}\left(0,5\right.$, and $\left.10 \mathrm{t} \mathrm{ha}^{-1}\right)$. Plants exposed to water stress presented a significant decrease in plant height, dry matter, leave area, chlorophyll content (SPAD), the quantum efficiency of photosystem II $\left(F_{v} / F_{m}, F_{v} / F_{0}\right.$, and PI), water status (membrane stability index and relative water content), and seed yield. Acidified biochar soil incorporation improved soil properties (chemical and physical), plant growth, physiological responses, WP, I-WUE, and contents of $\mathrm{N}, \mathrm{P}, \mathrm{K}$, and Ca. Results revealed that the application of ACBio at $10 \mathrm{tha}^{-1}$ and $5 \mathrm{tha}^{-1}$ significantly increased seed yield by 38.7 and $25.8 \%$, respectively, compared to the control. Therefore, ACBio incorporation may find application in the future as a potential soil amendment for improving growth and productivity of faba bean plants under deficit irrigation.
\end{abstract}

Keywords: drought stress; soil properties; physiological responses; faba bean and irrigation water use efficiency

\section{Introduction}

In arid and semi-arid countries, water shortage has an extreme effect on agricultural production. Therefore, there is increasing attention to improve water efficiency in agriculture. In the Mediterranean area where irrigation water is essential for the production of crops, farmers are searching for new tools to save water by enhancing the efficiency of water use. Globally, the faba bean (Vicia faba L.) is characterized as one of the most important legumes crops due to its importance for soil fertility, human nutrition as a good source of vegetarian protein, animal feeding, and industry purposes, also playing a vital 
role in the food chain. Moreover, it has become the most strategic crop due to its high income for farmers [1]. The seed of a faba bean is rich in carbohydrates (51-68\%) [2] and proteins (28-30\%) of dry matter [3]. In Egypt, the increasing quantity and quality of faba beans are major goals for meeting the demands of an increasing Egyptian population as faba beans are a main part of the diet of Egyptian people [4]. Water shortage has become a critical problem worldwide, especially in arid and semi-arid areas where water is required for growing crops [5]. In Mediterranean African countries, such as Egypt, the agriculture sector consumes nearly $80 \%$ of total water withdrawal. Therefore, developing policies is required to improve the efficiency of irrigation water use, while keeping the quantity and quality of crop production [6]. In the last decade, the challenge is the method of producing more yields from a restricted water supply. One way for attempting this problem is the approval of new practices that assist to improve water management, particularly under field conditions. Egypt faces various challenges, such as water scarcity initiated by human activities and environment variation, drought, and desertification. Therefore, emerging technical performs and using advanced irrigation-saving knowledge must be utilized for improving faba bean productivity. Deficit irrigation (DI) was initiated in agriculture to improve the efficiency of irrigated water [7-11]. Numerous researchers have documented the DI technique applied usually in water shortage conditions [10]. Much attention has been recently paid to sustainable agriculture development. Soil organic amendments are the most significant conservation agricultural practices for mitigating various abiotic stresses, for instance, drought, salinity, and heavy metals [11-18]. Biochar substances as a potential soil amendment in agriculture has been intensively reported in recent years to enhance plant growth and productivity as well as to alleviate the harmful impacts of different abiotic stresses and to improve soil structure and fertility [14,16,19-24]. A combination of acidified biochar and DI could be a promising practice among water management strategies for improving the efficiency of irrigation use. Biochar as organic amendments has a great role in improving soil aggregation, supplying nutrients, and motivating the microbial diversity and activity of soil $[23,24]$. The addition of biochar to soil has been revealed, in several experiments, to encourage soil alkalization by increasing $\mathrm{pH}$ values in acidic soil, which correspond to the increased contents of alkaline metals (i.e., $\mathrm{Mg}^{2+}, \mathrm{Ca}^{2+}$, and $\mathrm{K}^{+}$) oxides in biochars [25-30]. Egyptian soil is usually categorized by slightly alkaline to alkaline, mostly due to high temperatures, little rainfall, low relative humidity, and a high evaporation rate, leading to corrupted soil [31]. Soil alkalinity is considered the greatest problem in semi-arid and arid zones like Egypt and characterized by high $\mathrm{pH}$ values (7.5-8.7) [32]. Alkaline soils are described by the reduced availability of macro and micronutrients (i.e., $\mathrm{N}, \mathrm{P}, \mathrm{K}$, $\mathrm{Cu}, \mathrm{Fe}, \mathrm{Zn}$, and $\mathrm{Mn}$ ) and alkali stress generally includes a grouping of stresses, osmotic ion-induced damage, and increased soil $\mathrm{pH}$ [33-37]. Additionally, it has been widely reported that the suppling of biochar to soils has caused an increase of soil $\mathrm{pH}$ [38-40]. For these reasons, we added citric acid to citrus wood biochar $(3: 100(\mathrm{w} / \mathrm{w} /))$ to decrease the $\mathrm{pH}$ of biochar from 8.82 to 7.12 . To the best of our knowledge, this is the first attempt at investigating the combined effect of acidified biochar and deficit irrigation on faba beans. Thus, one of the main purposes of current investigation was to study how acidified biochar influences soil properties and consequently the growth and productivity, nutrient uptake, photosynthetic efficiency, and water use efficiency of drought-stressed faba bean plants.

\section{Materials and Methods}

\subsection{Experimental Set-Up}

In the successive growing seasons of 2016/17 and 2017/18, two field experiments were conducted at a private farm located in the El Fayoum region (latitudes $29^{\circ} 02^{\prime}$ and $29^{\circ} 35^{\prime} \mathrm{N}$ and longitudes $30^{\circ} 23^{\prime}$ and $31^{\circ} 05^{\prime} \mathrm{E}$ ), Egypt. According to [37], the soil is classified as arid climatic conditions. Table 1 shows soil properties (physical and chemical) of the experimental location which were analyzed according to the methods of [38,39]. 
Table 1. Some initial physical properties of the studied soils.

\begin{tabular}{|c|c|c|c|c|c|c|c|c|c|c|c|c|c|c|c|c|}
\hline \multirow[b]{2}{*}{$\begin{array}{l}\text { Layer } \\
(\mathrm{cm})\end{array}$} & \multicolumn{4}{|c|}{ Particle Size Distribution } & \multirow{2}{*}{$\begin{array}{c}\mathrm{Bd} \\
\mathrm{gcm}^{-3}\end{array}$} & \multirow[b]{2}{*}{$\begin{array}{c}\mathrm{K}_{\mathrm{sat}} \\
\mathrm{cmh}^{-1}\end{array}$} & \multicolumn{3}{|c|}{ Soil Moisture Content at } & \multirow[b]{2}{*}{$\begin{array}{c}\text { ECe } \\
\text { dS m }{ }^{-1}\end{array}$} & \multirow[b]{2}{*}{$\mathrm{pH}$} & \multirow[b]{2}{*}{$\begin{array}{c}\mathrm{OM} \\
\%\end{array}$} & \multirow[b]{2}{*}{$\begin{array}{c}\mathrm{CaCO}_{3} \\
\%\end{array}$} & \multirow[b]{2}{*}{$\begin{array}{l}N \\
(\%)\end{array}$} & \multirow{2}{*}{$\begin{array}{c}\mathbf{P} \\
\left(\mathrm{mg} \mathrm{kg}^{-1}\right. \\
\text { Soil) }\end{array}$} & \multirow{2}{*}{$\begin{array}{c}\mathrm{K} \\
\left(\mathrm{mg} \mathrm{kg}^{-1}\right. \\
\text { Soil) }\end{array}$} \\
\hline & $\begin{array}{c}\text { Sand } \\
\%\end{array}$ & $\begin{array}{c}\text { Silt } \\
\%\end{array}$ & $\begin{array}{c}\text { Clay } \\
\%\end{array}$ & $\begin{array}{c}\text { Texture } \\
\text { Class }\end{array}$ & & & $\begin{array}{c}\text { F.C } \\
\%\end{array}$ & $\begin{array}{c}\text { W.P } \\
\%\end{array}$ & $\begin{array}{c}\text { A. W } \\
\%\end{array}$ & & & & & & & \\
\hline $0-25$ & $\begin{array}{c}76.50 \pm \\
0.72\end{array}$ & $\begin{array}{c}12.50 \pm \\
0.47\end{array}$ & $\begin{array}{c}11.00 \pm \\
0.49\end{array}$ & LS & $\begin{array}{c}1.00 \pm \\
0.06\end{array}$ & $\begin{array}{c}2.13 \pm \\
0.08\end{array}$ & $\begin{array}{c}23.33 \pm \\
1.2\end{array}$ & $\begin{array}{c}10.73 \pm \\
0.39\end{array}$ & $\begin{array}{c}12.60 \pm \\
0.54\end{array}$ & $\begin{array}{c}7.23 \pm \\
0.12\end{array}$ & $\begin{array}{c}7.65 \pm \\
0.11\end{array}$ & $\begin{array}{c}1.53 \pm \\
0.04\end{array}$ & $\begin{array}{c}4.53 \pm \\
0.23\end{array}$ & $\begin{array}{c}0.003 \pm \\
0.00\end{array}$ & $\begin{array}{c}535.30 \pm \\
23\end{array}$ & $\begin{array}{c}48.36 \pm \\
2.06\end{array}$ \\
\hline $25-50$ & $\begin{array}{c}75.00 \pm \\
0.69\end{array}$ & $\begin{array}{c}12.80 \pm \\
0.51\end{array}$ & $\begin{array}{c}12.20 \pm \\
0.61\end{array}$ & LS & $\begin{array}{c}1.62 \pm \\
0.04\end{array}$ & $\begin{array}{c}1.98 \pm \\
0.09\end{array}$ & $\begin{array}{c}21.12 \pm \\
1.1\end{array}$ & $\begin{array}{c}9.50 \pm \\
0.36\end{array}$ & $\begin{array}{c}11.62 \pm \\
0.46\end{array}$ & $\begin{array}{c}6.98 \pm \\
0.13\end{array}$ & $\begin{array}{c}7.74 \pm \\
0.09\end{array}$ & $\begin{array}{c}1.20 \pm \\
0.03\end{array}$ & $\begin{array}{c}4.21 \pm \\
0.22\end{array}$ & $\begin{array}{c}0.003 \pm \\
0.00\end{array}$ & $\begin{array}{c}544.61 \pm \\
19\end{array}$ & $\begin{array}{c}45.31 \pm \\
1.99\end{array}$ \\
\hline
\end{tabular}

$\mathrm{LS}=$ loamy sand, $\mathrm{Bd}=$ bulk density, Ksat = hydraulic conductivity F.C = field capacity, W.P = wilting point, A.W = available water, ECe = the average of electrical conductivity, and O.M = organic matter 
The experiments were conducted in randomized block design with split plot. Treatments were divided into three irrigation water applications (IWA) and three acidified biochar (ACBio) rates. Irrigation was applied as a percentage of the ETc, representing one of the following three treatments: $\left(\mathrm{I}_{100}=100 \%, \mathrm{I}_{80}=80 \%\right.$, and $\mathrm{I}_{60}=60 \%$ of ETc). Irrigation treatments were distributed in the main plots, while acidified biochar treatments namely $\left(\mathrm{ACBio}_{0}=0 \mathrm{t} \mathrm{ha}^{-1}\right.$, as a control, $\mathrm{ACBio}_{5}=5 \mathrm{tha}^{-1}$, and ACBio $\left.10=10 \mathrm{tha}^{-1}\right)$ were allotted in the sub-plots.

Three weeks before sowing faba beans, ACBio (3:100 (w/w/) combination of citric acid, and citrus wood biochar] was incorporated in the soil. Properties of the acidified biochar (ACBio) used in these experiments were presented in Table 2. A total of 9 treatments were replicated three times and the total experimental plots were 27 . The experimental plot area was $18 \mathrm{~m}$ (length) $\times 0.8 \mathrm{~m}$ (row width) $\left(14.4 \mathrm{~m}^{2}\right)$, each plot involved 3 planting rows and the space between plants within rows was $15 \mathrm{~cm}$.

Table 2. Acidified biochar properties.

\begin{tabular}{ccc}
\hline Attribute & Unit & Value \\
\hline BD & $\mathrm{g} \mathrm{cm}^{-3}$ & 0.79 \\
$\mathrm{EC}$ & $\mathrm{dS} \mathrm{m}^{-1}$ & 1.62 \\
$\mathrm{pH}$ & & 7.12 \\
$\mathrm{MC}$ & & 19.60 \\
$\mathrm{C}$ & $\%$ & 42.70 \\
$\mathrm{Ash}$ & & 35.70 \\
$\mathrm{CEC}$ & $\mathrm{cmol}+/ \mathrm{kg}$ & 46.50 \\
Macronutrients & & 1.48 \\
$\mathrm{~N}$ & $\%$ & 0.078 \\
$\mathrm{P}$ & & 3495 \\
$\mathrm{~K}$ & & 4435 \\
$\mathrm{Ca}$ & & $<11$ \\
$\mathrm{Na}$ & & 74.00 \\
Micronutrients & $\mathrm{mg} \mathrm{kg}$ & 83.00 \\
$\mathrm{Zn}$ & & 569.00 \\
Fe & & 21.00 \\
$\mathrm{Mn}$ & & \\
$\mathrm{Cu}$ & & \\
\hline
\end{tabular}

$\mathrm{BD}$ is the bulk density, $\mathrm{MC}$ is moisture content, and CEC is the cation exchange capacity.

\subsection{Agronomic Management}

Healthy seeds of faba bean (Vicia faba. L., cultivar Sakha 1) were sown on 8 and 10 October of 2016/17 and 2017/18 and harvested on 15 and 20 April of 2016/2017 and $2017 / 2018$. The used system of irrigation was drip irrigation and 2 drip-lines placed $0.5 \mathrm{~m}$ apart in each elementary test plot. Irrigation treatments were started after full germination. Calcium superphosphate $\left(15.5 \% \mathrm{P}_{2} \mathrm{O}_{5}\right)$, as a source of phosphorus $\left(370 \mathrm{~kg} \mathrm{ha}^{-1}\right)$ was added to the soil through the preparation of seedbed $150 \mathrm{~kg} \mathrm{ha}^{-1}$ in the form of ammonium nitrate $(33.5 \% \mathrm{~N})$, added in 2 doses through the growing seasons (20 and 40 days after sowing) as a source of nitrogen. In addition, $125 \mathrm{~kg} \mathrm{ha}^{-1}$ potassium sulphate $\left(50 \% \mathrm{~K}_{2} \mathrm{O}\right)$ was added after 75 days of the sowing date. All cultural practices were done according to recommendations of the Ministry of Agriculture, Egypt.

\subsection{Irrigation Water Applied (IWA)}

The amounts of water were determined according to [40] by using the following equation:

$$
\mathrm{IWA}=\frac{\mathrm{A} \times \mathrm{ETc} \times \mathrm{Ii}}{\mathrm{Ea} \times(1-\mathrm{LR})}
$$

where IWA is the irrigation water applied $\left(\mathrm{m}^{3}\right), \mathrm{A}$ is the plot area $\left(\mathrm{m}^{2}\right)$, ETc is the evapotranspiration $\left(\mathrm{mm} \mathrm{d}^{-1}\right)$, Ii is the irrigation interval (day), Ea is the application efficiency 
$(\%)$, and LR is the leaching requirements. ETc was estimated using the crop coefficient according to [40] equation:

$$
\mathrm{ETc}=\mathrm{Kpan} \times \mathrm{Epan} \times \mathrm{Kc}
$$

where Kpan = pan evaporation coefficient, Epan = evaporation from the Class A pan $\left(\mathrm{mm} \mathrm{d}^{-1}\right)$, and $\mathrm{Kc}=$ crop coefficient.

\subsection{Growth, Physiological, and Water Statutes Measurements}

A total of 90 days after sowing, date samples of faba bean plants were collected from plots to determine the number of leaf per plant ${ }^{1}$, plant height, number of branches per plant, leaf area, and dry weight per plant ${ }^{1}$. Chlorophyll fluorescence $\left(F v / F m, F_{v} / F_{0}\right.$, and PI), as a convenient tool to assess photosynthetic efficiency, was determined according to [41,42] by Handy PEA, Hansatech Instruments (Ltd., Kings Lynn, UK). The values of membrane stability index (MSI\%) and relative water content (RWC\%) were determined according to [43,44] respectively. SPAD chlorophyll meter (SPAD-502; Minolta, Osaka, Japan) was used to determine the relative contents of chlorophyll.

\subsection{Nutrients Determinations}

The leaf nutrient contents ( $\mathrm{N}, \mathrm{P}, \mathrm{K}, \mathrm{Ca}$, and $\mathrm{Na}$ ) of faba beans were measured after being oven dried and wet digestion with $\mathrm{HNO}_{3}$ and $\mathrm{H}_{2} \mathrm{O}_{2}$ samples were analyzed for $\mathrm{P}$ content spectrophotometrically [45] and for $\mathrm{K}^{+}, \mathrm{Ca}^{2+}$, and $\mathrm{Na}^{+}$contents by Flame photometry (Gallenkamp Co., London, UK). The N content was estimated by Kjeldahl digestion method (Ningbo Medical Instruments Co., Ningbo, China).

\subsection{Yield, Water Productivity, and Irrigation-Water Use Efficiency}

At the harvesting stage, 10 randomly guarded plants were taken from each plot and used to determine yield components, i.e., number of pods per plant, pods weight plant ${ }^{-1}$, and 100-seed weight. Seeds of all plants per plot were utilized to determine seed yield $\left(\mathrm{t} \mathrm{ha}{ }^{-1}\right)$. Water productivity (WP) and irrigation water use efficiency (I-WUE) indices were calculated using the following equations:

$$
\begin{gathered}
\mathrm{WP}=\frac{\text { seed yield }\left(\mathrm{Kg} \mathrm{ha}^{-1}\right)}{\text { water applied }(\mathrm{mm})}, \\
\mathrm{I}-\mathrm{WUE}=\frac{\text { seed yield }\left(\mathrm{Kg} \mathrm{ha}^{-1}\right)}{\text { evapotranspiration }(\mathrm{mm})} .
\end{gathered}
$$

\subsection{Statistical Analysis}

The results were statistically analyzed according to [46] using ANOVA procedures in a GenStat statistical package (version 11) (VSN International Ltd., Oxford, UK).

\section{Results and Discussion}

\subsection{Effect of Acidified Biochar on Soil Characteristics}

Data presented in Table 3 show the impact of ACBio application on soil physicochemical properties. Soil bulk density, ECe, and $\mathrm{pH}$ strongly declined with increasing ACBio applications. Furthermore, the total porosity, field capacity (FC \%), nitrogen content $(\mathrm{N} \%)$, phosphorus $(\mathrm{P})$, and potassium $(\mathrm{K})\left(\mathrm{mg} \mathrm{kg}^{-1}\right.$ soil) increased by adding ACBio (Table 3). Data revealed that ECe values decreased from 7.2 at control to 6.96 and 6.73 at $\mathrm{ACBio}_{5}$ and $10 \mathrm{t} \mathrm{h}^{-1}$, as an average for $\mathrm{S}_{\mathrm{I}}$ and $\mathrm{S}_{\mathrm{II}}$ years, respectively. Likewise, soil $\mathrm{pH}$ decreased from 7.69 at $\mathrm{ACBio}_{0}$ to 7.50 and 7.35 at the rate of $\mathrm{ACBio}_{5}$ and $10 \mathrm{th}^{-1}$, respectively. The values of bulk density decreased (from 1.55 to 1.47 and $1.44 \mathrm{~g} \mathrm{~cm}^{-3}$ ) when ACBio applications increased from 0 to 5 and $10 \mathrm{tha}^{-1}$. In contrast, organic matter $(\mathrm{OM} \%)$ was increased gradually from $1.19 \%$ to 1.79 and / or $2.0 \%$ with the increasing ACBio application from 0 to 5 and $10 \mathrm{tha}^{-1}$, respectively. 
Table 3. Effect of acidified biochar rates on some physical and chemical properties at harvesting stage for $\mathrm{S}_{\mathrm{I}}$ (2016/17) and $\mathrm{S}_{\text {II }}(2017 / 18)$ seasons.

\begin{tabular}{|c|c|c|c|c|c|c|c|c|c|}
\hline $\begin{array}{l}\text { ACBio } \\
\left(t^{-1}\right)\end{array}$ & $\begin{array}{c}\text { ECe } \\
\left(\mathrm{dS} \mathrm{m}^{-1}\right)\end{array}$ & $\begin{array}{l}\text { Soil } \\
\text { pH }\end{array}$ & $\underset{\%}{\mathrm{O} . \mathrm{M}}$ & $\begin{array}{c}\mathrm{N} \\
(\%)\end{array}$ & $\begin{array}{c}\mathbf{P} \\
\text { (mg kg }^{-1} \\
\text { Soil) }\end{array}$ & $\begin{array}{c}\mathrm{K} \\
\begin{array}{c}\text { (mg kg-1 } \\
\text { Soil) }\end{array}\end{array}$ & $\begin{array}{c}\text { Total } \\
\text { Porosity \% }\end{array}$ & $\begin{array}{c}\text { Bulk } \\
\text { Density } \\
\mathrm{g} \mathrm{cm}^{-3}\end{array}$ & $\begin{array}{c}\text { F.C } \\
\%\end{array}$ \\
\hline \multicolumn{10}{|c|}{$\mathrm{S}_{\mathrm{I}}(2016 / 17)$} \\
\hline $\mathrm{ACBio}_{0}$ & $\begin{array}{c}7.30 \pm 0.88 \\
a^{\Gamma}\end{array}$ & $\begin{array}{c}7.70 \pm 1.12 \\
a\end{array}$ & $\begin{array}{c}1.18 \pm 0.11 \\
\mathrm{c}\end{array}$ & $\begin{array}{c}0.003 \pm 0.00 \\
\mathrm{c}\end{array}$ & $\begin{array}{c}518.54 \pm \\
23.1 \mathrm{~b}\end{array}$ & $\begin{array}{c}41.00 \pm 3.51 \\
c\end{array}$ & $\begin{array}{c}32.21 \pm 2.88 \\
b\end{array}$ & $\begin{array}{c}1.54 \pm 0.12 \\
\mathrm{a}\end{array}$ & $\begin{array}{c}22.24 \pm 2.14 \\
b\end{array}$ \\
\hline $\mathrm{ACBio}_{5}$ & $\begin{array}{c}7.02 \pm 1.13 \\
b\end{array}$ & $\begin{array}{c}7.52 \pm 0.98 \\
b\end{array}$ & $\begin{array}{c}1.86 \pm 0.15 \\
\mathrm{~b}\end{array}$ & $\begin{array}{c}0.007 \pm 0.00 \\
\mathrm{~b}\end{array}$ & $\begin{array}{c}698.68 \pm \\
25.31 \mathrm{a}\end{array}$ & $\begin{array}{c}49.42 \pm 3.62 \\
b\end{array}$ & $\begin{array}{c}37.71 \pm 3.14 \\
\mathrm{a}\end{array}$ & $\begin{array}{c}1.49 \pm 0.11 \\
b\end{array}$ & $\begin{array}{c}26.17 \pm 3.10 \\
\mathrm{ab}\end{array}$ \\
\hline $\mathrm{ACBio}_{10}$ & $\begin{array}{c}6.79 \pm 0.97 \\
c\end{array}$ & $\begin{array}{c}7.38 \pm 1.21 \\
\mathrm{c}\end{array}$ & $\begin{array}{c}2.01 \pm 0.12 \\
\mathrm{a}\end{array}$ & $\begin{array}{c}0.021 \pm 0.00 \\
\mathrm{a}\end{array}$ & $\begin{array}{c}647.21 \pm \\
32.1 \mathrm{a}\end{array}$ & $55.68 \pm 4.2 \mathrm{a}$ & $\begin{array}{c}38.00 \pm 3.41 \\
\mathrm{a}\end{array}$ & $\begin{array}{c}1.45 \pm 0.11 \\
\mathrm{~b}\end{array}$ & $\begin{array}{c}27.45 \pm 2.84 \\
\mathrm{a}\end{array}$ \\
\hline \multicolumn{10}{|c|}{$\mathrm{S}_{\text {II }}(2017 / 18)$} \\
\hline $\mathrm{ACBio}_{0}$ & $\begin{array}{c}7.10 \pm 1.11 \\
\mathrm{a}\end{array}$ & $\begin{array}{c}7.67 \pm 1.03 \\
\mathrm{a}\end{array}$ & $\begin{array}{c}1.20 \pm 0.10 \\
c\end{array}$ & $\begin{array}{c}0.003 \pm 0.00 \\
c\end{array}$ & $\begin{array}{c}526.24 \pm \\
28.63 \mathrm{~b}\end{array}$ & $\begin{array}{c}42.34 \pm 4.12 \\
c\end{array}$ & $\begin{array}{c}33.66 \pm 2.13 \\
b\end{array}$ & $\begin{array}{c}1.56 \pm 0.11 \\
\mathrm{a}\end{array}$ & $\begin{array}{c}24.32 \pm 2.45 \\
b\end{array}$ \\
\hline $\mathrm{ACBio}_{5}$ & $\begin{array}{c}6.90 \pm 1.01 \\
b\end{array}$ & $\begin{array}{c}7.48 \pm 1.11 \\
\mathrm{~b}\end{array}$ & $\begin{array}{c}1.71 \pm 0.12 \\
\mathrm{~b}\end{array}$ & $\begin{array}{c}0.008 \pm 0.00 \\
\mathrm{~b}\end{array}$ & $\begin{array}{c}610.14 \pm \\
27.89 \mathrm{a}\end{array}$ & $\begin{array}{c}53.67 \pm 4.65 \\
b\end{array}$ & $\begin{array}{c}38.21 \pm 2.56 \\
\mathrm{a}\end{array}$ & $\begin{array}{c}1.44 \pm 0.13 \\
\mathrm{~b}\end{array}$ & $\begin{array}{c}27.67 \pm 1.63 \\
a b\end{array}$ \\
\hline $\mathrm{ACBio}_{10}$ & $\begin{array}{c}6.66 \pm 1.20 \\
c\end{array}$ & $\begin{array}{c}7.31 \pm 1.17 \\
\mathrm{c}\end{array}$ & $\begin{array}{c}1.98 \pm 0.01 \\
\mathrm{a}\end{array}$ & $\begin{array}{c}0.022 \pm 0.00 \\
\mathrm{a}\end{array}$ & $\begin{array}{c}659.43 \pm \\
33.24 \mathrm{a}\end{array}$ & $\begin{array}{c}58.37 \pm 3.89 \\
\mathrm{a}\end{array}$ & $\begin{array}{c}39.26 \pm 3.11 \\
\mathrm{a}\end{array}$ & $\begin{array}{c}1.43 \pm 0.12 \\
\mathrm{~b}\end{array}$ & $\begin{array}{c}29.67 \pm 2.04 \\
\mathrm{a}\end{array}$ \\
\hline
\end{tabular}

$\Gamma$ Treatment means with the same letter are not significant at the $p \leq 0.05$ level.

O.M means organic matter and F.C means field capacity. The N, P, and K contents increased in $\mathrm{ACBio}_{5}$ or $\mathrm{ACBio}_{10}$ compared with the control. Among the integrative treatments, the application of $10 \mathrm{tha}^{-1}$ was the best treatment and soil contents of $\mathrm{N}, \mathrm{P}$, and $\mathrm{K}$ were $133,653.3$, and $57.02 \%$ ( $\mathrm{mg} \mathrm{kg}^{-1}$ soil), respectively. On the other hand, the addition of ACBio at 5 and $10 \mathrm{tha}^{-1}$ increased the total porosity by 15.3 and $17.3 \%$ and field capacity by 15.6 and $22.7 \%$, compared with the control as an average for both seasons. The improvements of soil quality after amendment with acidified biochar could be clarified by an increase in the nutrient adding and retention as a result of their supply to the soil [47-49]. These findings are in harmony with [50]. They concluded that some physical and chemical soil properties (total porosity, water holding capacity, bulk density, OM\%, content of soil elements, and NPK) can likewise improve with the suppling of biochar.

\subsection{Effect of Acidified Biochar on Nutrients Status of Faba Bean Plants}

The addition of ACBio strongly increased faba bean leaf contents of macronutrients $\left(\mathrm{N}, \mathrm{P}, \mathrm{K}^{+}\right.$, and $\mathrm{Ca}^{2+}$ ) compared to the non-treated soil. On the other hand, faba bean leaf $\mathrm{Na}^{+}$content and $\mathrm{Na}^{+} / \mathrm{K}^{+}$ratio decreased significantly by the addition of ACBio (Table 4) for both seasons. The $\mathrm{Na}^{+} / \mathrm{K}^{+}$ratio and $\mathrm{Na}^{+}$content in the leaves of faba bean decreased at $\mathrm{ACBio}_{10}$ compared to $\mathrm{ACBio}_{0}$. Data in Table 4 show that, with increasing ACBio application from 0 to 5 and $10 \mathrm{tha}^{-1}$, the content of $\mathrm{N}$ increased by 20.9 and $22.5 \%$, P by 25.4 and $16.9 \%$, $\mathrm{K}$ by 20.7 and $28.0 \%$, and Ca by 48.2 and $76 \%$ as an average for both seasons. These findings agree with those of [25]. They observed that the addition of biochar resulted in an increase of macronutrient uptake in maize. Furthermore, soil amended with 5 and $10 \mathrm{tha}^{-1}$ of ACBio decreased $\mathrm{Na}$ and $\mathrm{Na}^{+} / \mathrm{K}^{+}$by 27.0 and $27.6 \%$ for $\mathrm{Na}$ and by 40 and $43.3 \%$ for $\mathrm{Na}^{+} / \mathrm{K}^{+}$compared with unamended soil, respectively. The results agree with $[16,24]$. They noted that biochar utilization has positive effects in decreasing $\mathrm{Na}^{+}$uptake in plants. The increase of $\mathrm{N}, \mathrm{P}, \mathrm{K}$, and Ca uptake by faba bean plants are most likely because of the induced improvement in chemical soil properties i.e., total $\mathrm{N}$ and available $\mathrm{P}_{2} \mathrm{O}_{5}$ contents, $\mathrm{pH}$ value, and CEC. Lower $\mathrm{pH}$ values of amended soil (Table 3 ) probably improved the nutrients status of faba bean plants. Hence this reduction in soil $\mathrm{pH}$, lead to the increasing mineralization of organic materials and solubilization of elements particularly in the rhizosphere, which could have resulted in increased bioavailability of crucial elements in soil and ultimately their uptake and assimilation in faba bean plants. These results are in assenting with those obtained by [51]. The content of $\mathrm{Na}\left(\mathrm{g} \mathrm{kg}^{-1}\right)$ decreased gradually with increasing rates of acidified biochar (ACBio) from 19.1 in control to 13.8 in $\mathrm{ABCio}_{10}$ in the second season. However, the ratio of $\mathrm{Na}^{+} / \mathrm{K}^{+}$decreased under 
$\mathrm{ACBio}_{5}$ or $\mathrm{ACBio}_{10}$ compared with the control. Biochar addition may or may not bring positive impacts on crop productivity depending on soil properties. Biochar integrated with fertilizers caused an increase in yields [52].

Table 4. Effect of acidified biochar rates on nutrients status $\left(\mathrm{N}, \mathrm{P}, \mathrm{K} \mathrm{Ca}, \mathrm{Na}\right.$, and $\mathrm{Na}^{+} / \mathrm{K}^{+}$ratio) of faba been plants for $\mathrm{S}_{\mathrm{I}}$ $(2016 / 17)$ and $\mathrm{S}_{\mathrm{II}}(2017 / 18)$ seasons.

\begin{tabular}{|c|c|c|c|c|c|c|}
\hline $\begin{array}{l}\text { ACBio } \\
\left(t h^{-1}\right)\end{array}$ & $\begin{array}{c}\mathrm{N} \\
(\mathrm{g} / \mathrm{kg})\end{array}$ & $\begin{array}{c}P \\
(g / k g)\end{array}$ & $\underset{(g / k g)}{K}$ & $\begin{array}{c}\mathrm{Ca} \\
(\mathrm{g} / \mathrm{kg})\end{array}$ & $\begin{array}{c}\mathrm{Na}^{+} \\
(\mathrm{g} / \mathrm{kg})\end{array}$ & $\mathrm{Na}^{+} / \mathrm{K}^{+}$ \\
\hline \multicolumn{7}{|c|}{$\mathrm{S}_{\mathrm{I}}(2016 / 17)$} \\
\hline $\mathrm{ACBio}_{0}$ & $21.7 \pm 0.43 \mathrm{~b}^{\Gamma}$ & $2.01 \pm 0.36 \mathrm{c}$ & $21.5 \pm 0.59 \mathrm{~b}$ & $4.25 \pm 0.25 b$ & $19.5 \pm 0.41 \mathrm{a}$ & $0.91 \pm 0.12 \mathrm{a}$ \\
\hline $\mathrm{ACBiO}_{5}$ & $26.2 \pm 2.20 \mathrm{a}$ & $2.7 \pm 0.22 \mathrm{a}$ & $25.3 \pm 0.16 \mathrm{a}$ & $6.54 \pm 0.61 \mathrm{a}$ & $14.2 \pm 0.17 b$ & $0.56 \pm 0.11 c$ \\
\hline $\mathrm{ACBio}_{10}$ & $26.7 \pm 0.22 \mathrm{a}$ & $2.41 \pm 0.16 b$ & $26.7 \pm 0.46 \mathrm{a}$ & $7.91 \pm 0.75 \mathrm{a}$ & $14.7 \pm 0.45 b$ & $0.55 \pm 0.10 b$ \\
\hline \multicolumn{7}{|c|}{$\mathrm{S}_{\mathrm{II}}(2017 / 18)$} \\
\hline $\mathrm{ACBio}_{0}$ & $22.3 \pm 0.36 \mathrm{~b}$ & $2.13 \pm 0.37 c$ & $21.0 \pm 0.69 \mathrm{~b}$ & $5.25 \pm 0.42 c$ & $18.6 \pm 0.28 \mathrm{a}$ & $0.89 \pm 0.14 a$ \\
\hline $\mathrm{ACBiO}_{5}$ & $27.0 \pm 1.50 \mathrm{a}$ & $2.73 \pm 0.22 \mathrm{a}$ & $26.0 \pm 0.17 \mathrm{a}$ & $7.54 \pm 0.46 b$ & $13.6 \pm 0.23 b$ & $0.52 \pm 0.09 c$ \\
\hline $\mathrm{ACBio}_{10}$ & $27.2 \pm 0.10 \mathrm{a}$ & $2.55 \pm 0.16 b$ & $27.7 \pm 0.42 \mathrm{a}$ & $8.81 \pm 0.87 \mathrm{a}$ & $12.9 \pm 0.32 b$ & $0.47 \pm 0.12 b$ \\
\hline
\end{tabular}

$\Gamma$ Treatment means with the same letter are not significant at the $p \leq 0.05$ level.

\subsection{Chlorophyll Relative Index (SPAD Value) and Chlorophyll Fluorescence}

The interactive effects of ACBio and IWA on chlorophyll content (SPAD value), chlorophyll fluorescence $(\mathrm{Fv} / \mathrm{Fm})$, and the performance index (PI) were introduced in Figures 1 and 2 . These parameters were affected negatively $(p \leq 0.05)$, gradually with the increase of irrigation stress during both growing seasons (( $\mathrm{S}_{\mathrm{I}}(2016 / 17)$ and $\left.\mathrm{S}_{\mathrm{II}}(2017 / 18)\right)$. On the other hand, the suppling of ACBio mitigated the harmful stress on the SPAD value, $\mathrm{Fv} / \mathrm{Fm}$, and PI created by a water deficit.

In both seasons, the highest values of SPAD, Fv/Fm, and PI were recorded when faba bean plants were well irrigated $\left(\mathrm{I}_{100}\right)$ and supplied with $10 \mathrm{tha}^{-1}$ of ACBio. Likewise, lower values of SPAD, Fv / Fm, and PI were noted in ACBio $+\mathrm{I}_{60 \%}$ treatment. Faba bean plants had higher values of SPAD, Fv /Fm, and PI, produced higher pods number, pods weight $(\mathrm{g})$, and consequently an increase in seed yield $\left(\mathrm{t} \mathrm{ha} \mathrm{a}^{-1}\right)$. Many works stated that the values of chlorophyll fluorescence could be considered as a reliable tool for evaluating the fluctuations that occurred in the function of PSII in different stresses [53-55]. We observed a reduction in values of the efficiency of the photosystem's (Fv/Fm, and PI) relative content of chlorophyll (SPAD) under severe water conditions, which might have been due to the decrease in faba bean water status ((MSI\% and RWC) (Figure 2)) necessary for photosynthesis. This is consistent with the results of other authors $[54,56]$. Various investigations have summarized that the disturbance of water supply leaded to a decrease in water content in absorption tissue, and thus, prompts photosynthetic discouragement $[49,57,58]$. 
(Sı) 2016/17
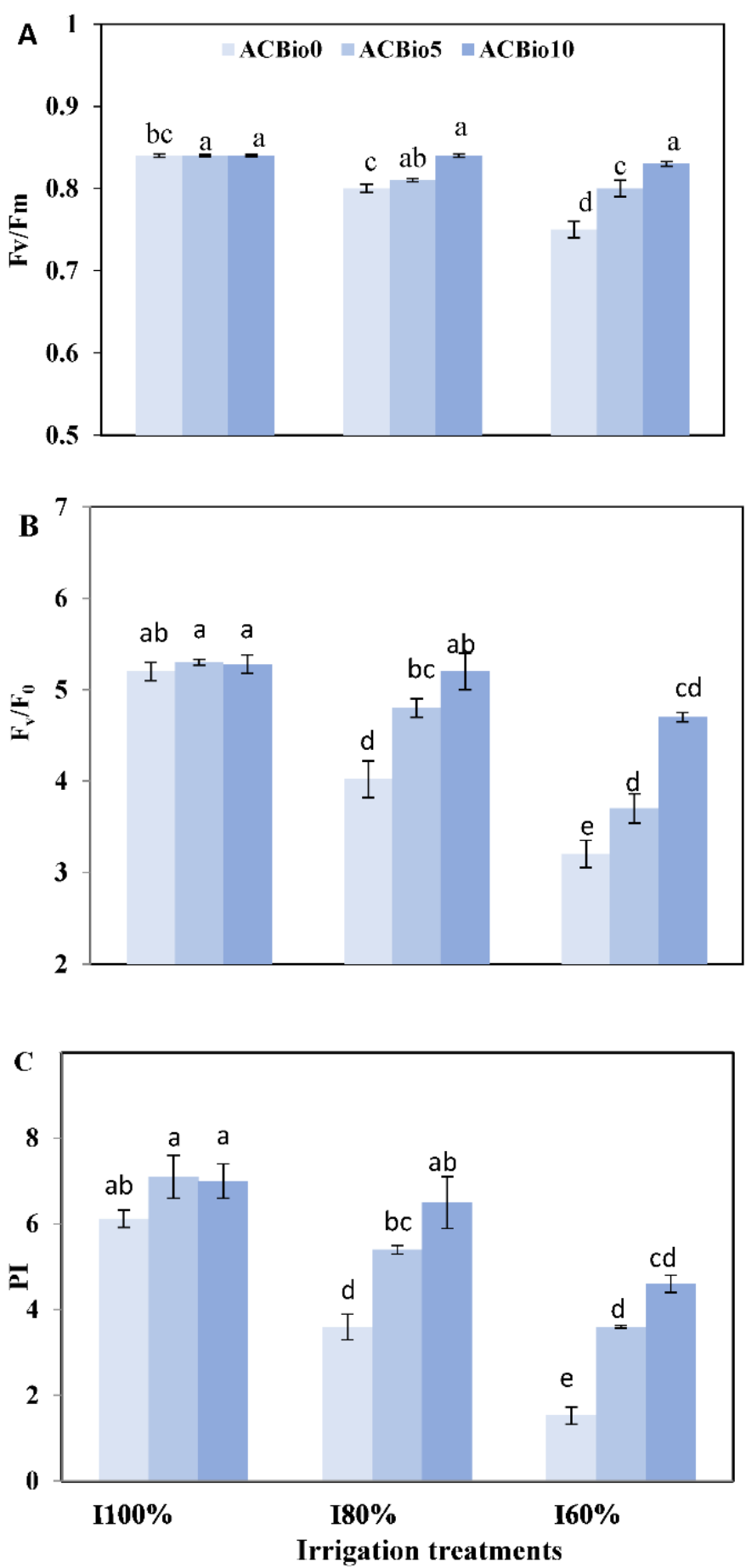

(SII) 2017/18
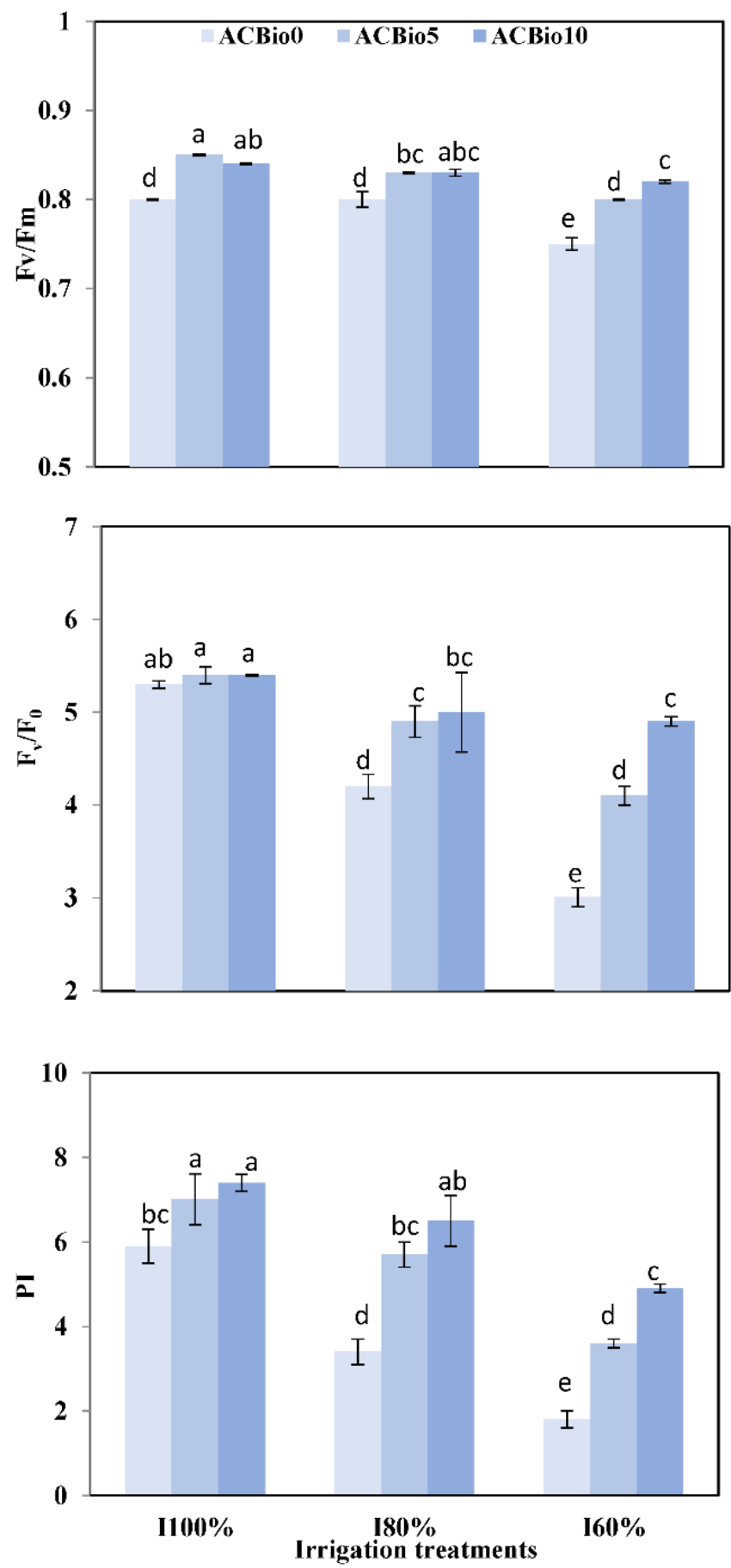

Figure 1. Leaf chlorophyll fluorescence parameter of faba bean plants grown under irrigation treatments $\left(\mathrm{I}_{100}\right.$, irrigation with $100 \%$; $\mathrm{I}_{80}$, irrigation with $80 \%$; and $\mathrm{I}_{60}$, irrigation with $60 \%$ of ETc) and acidified biochar rates in $2016 / 17$ and 2017/18 seasons. (A) Maximum quantum efficiency of PSII $\left(F_{v} / F_{m}\right)$; (B) potential photochemical efficiency $\left(F_{v} / F_{0}\right)$; and (C) performance index $(P I)$. Vertical bars represent means of 3 replications \pm S.E $(p \leq 0.05)$. Columns marked by different letters are significantly different. 

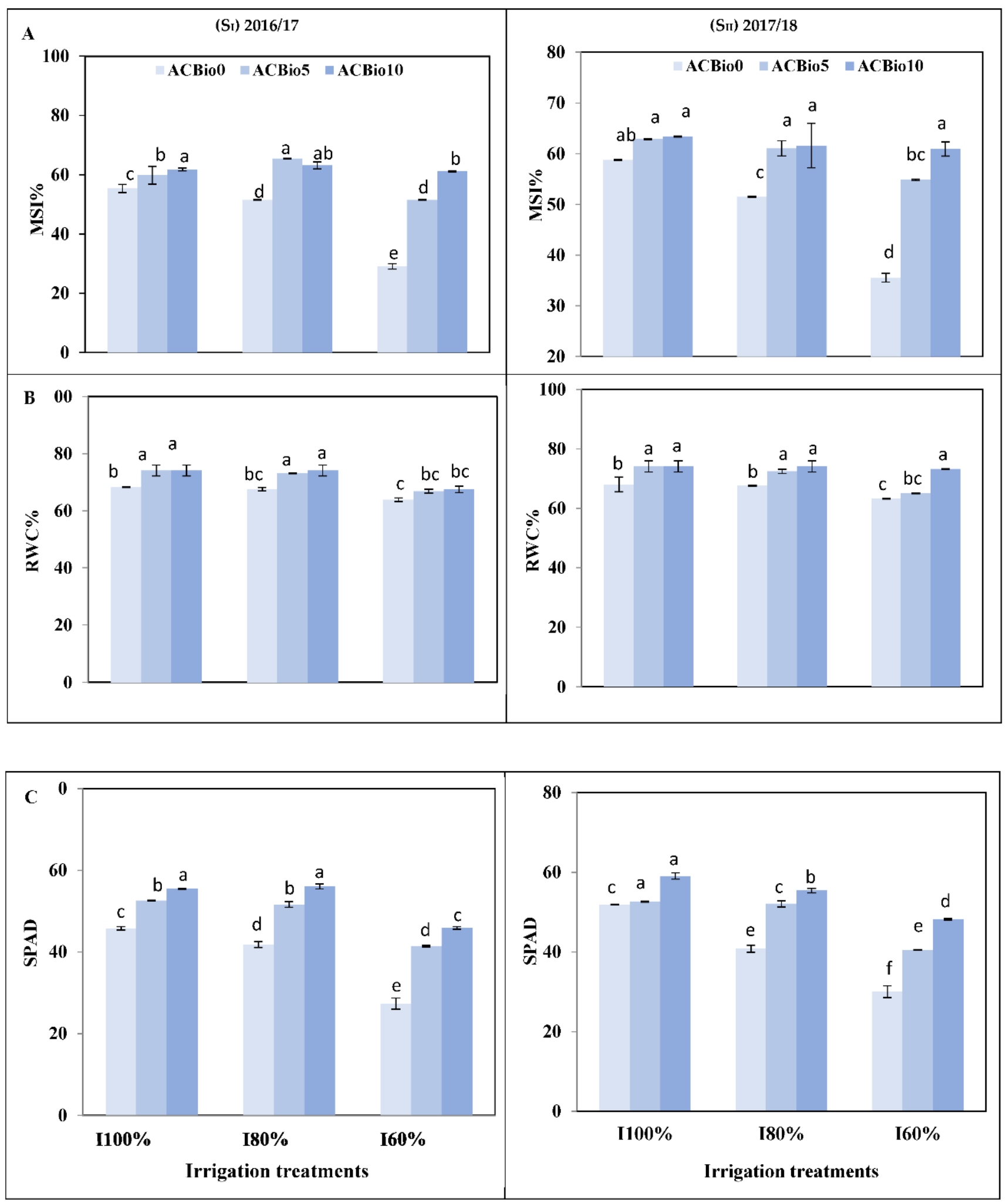

Figure 2. Effect of acidified biochar on (A) membrane stability index (MSI \%), (B) relative water content (RWC \%), and (C) chlorophyll content (SPAD) of faba bean plants grown under different irrigation treatments $\left(\mathrm{I}_{100 \%}, \mathrm{I}_{80} \%\right.$, and $\mathrm{I}_{60 \%}$ of ETc) in $\mathrm{S}_{\mathrm{I}}(2016 / 17)$ and $\mathrm{S}_{\mathrm{II}}(2017 / 18)$ seasons. Vertical bars represent means of 3 replications \pm S.E $(p \leq 0.05)$. Columns marked by different letters are significantly different. 


\subsection{Faba Bean Water Status}

The impacts of the ACBio and IWA on faba bean RWC\% and MSI\% indices are shown in Figure 2. Both indices were affected by both the ACBio and IWA $(p \leq 0.05)$ and the highest values recorded during $S_{I}(2016 / 17)$ than $S_{\text {II }}(2017 / 18)$. According to the statistical analysis, the interaction between ACBio and IWA were positively affected $(p \leq 0.05)$ on RWC $\%$ and MSI $\%$. The values of RWC $\%$ and MSI $\%$ tended to decrease with increasing water stress. However, the addition of ACBio was found to modify the IWA-affected RWC $\%$ and MSI $\%$. The highest values of RWC $\%$ and MSI $\%$ were obtained under $\mathrm{ACBio}_{10}$ $+\mathrm{I}_{100}$ treatment for both seasons. Water stress had a strong impact on the RWC $\%$ and MSI\% of faba bean leaves. RWC is a significant indicator of water status in crops or plants; it reveals the equilibrium between the transpiration rate and water supply to the leaf tissue $[56,59,60]$. Our results show that the addition of acidified biochar to saline soil under drought stress alleviated abiotic stresses by maintaining a higher RWC $\%$ and $\mathrm{MSI} \%$ (Figure 2), lower $\mathrm{Na}^{+} / \mathrm{K}^{+}$ratio (Table 4), and further improved the photosynthesis of faba bean leaves (Figure 1). This is consistent with the results of other authors $[14,16,25]$ who reported increased plant water status because of the high adsorption capacity of biochar for water, which then increased the soil water content.

\subsection{Faba Bean Growth Attributes}

Plant height, leaves number plant ${ }^{-1}$, number of branches plant ${ }^{-1}$, dry matter plant ${ }^{-1}$, and leaves area plant ${ }^{-1}$ are analyzed statistically and presented in Tables 5 and 6. All growth parameters were highly significantly affected by IWA and ACBio. Among growth characteristics, leaves area and dry matter plant $^{-1}$ were affected by seasons. All growth traits were significantly affected by the interaction between the acidified biochar and irrigation regime. The highest values of all parameters had been registered when plants of faba bean were subjected to $\mathrm{I}_{100 \%}$ combined with $10 \mathrm{t} \mathrm{ha}^{-1}$ of acidified biochar $\left(\mathrm{ACBio}_{10}\right)$ as the average for both seasons. On the other hand, the lowest values were recorded under $\mathrm{I}_{60 \%}+\mathrm{ACBio}_{0}$. Plant height, leaf number, branch number, leaf area, and dry matter were strongly reduced in $\mathrm{I}_{60 \%}$. Suppling ACBio clearly affected plant growth and the production of biomass. The enhanced growth traits may be due to the increase decomposition of the ACBio and mineralization of nutrients [61]. Our results showed that the utilization of 5 and $10 \mathrm{tha}^{-1}$ of ACBio significantly increased the growth attributes compared to $\mathrm{ACBio}_{0}$. The enhancement observed in growth characteristics could be attributed to the nutrient availability after the application of ACBio.

Table 5. Means and standard errors for plant height, leaf number, branch number, dry matter, and leaf area.

\begin{tabular}{|c|c|c|c|c|c|}
\hline \multicolumn{6}{|c|}{ Mean \pm SE } \\
\hline Item & $\begin{array}{l}\text { Plant Height } \\
\text { (cm) }\end{array}$ & $\begin{array}{l}\text { Leave } \\
\text { No. }\end{array}$ & $\begin{array}{c}\text { Branch } \\
\text { No. }\end{array}$ & $\begin{array}{c}\text { Dry } \\
\text { Matter } \\
\text { (g) }\end{array}$ & $\begin{array}{l}\text { Leave Area } \\
\qquad\left(\mathrm{dm}^{2}\right)\end{array}$ \\
\hline Years & NS & NS & NS & * & $*$ \\
\hline $\mathrm{S}_{\mathrm{I}}$ & $106.6 \pm 1.6^{\mathrm{a}}$ & $20.70 \pm 0.56^{\mathrm{a}}$ & $5.5 \pm 0.21^{\mathrm{a}}$ & $55.0 \pm 2.4^{b}$ & $156.1 \pm 5.4^{b}$ \\
\hline $\mathrm{S}_{\text {II }}$ & $102.7 \pm 1.5^{\mathrm{a}}$ & $22.1 \pm 0.59^{a}$ & $5.2 \pm 0.22^{b}$ & $62.4 \pm 1.2^{\mathrm{a}}$ & $175.2 \pm 2.5^{\mathrm{a}}$ \\
\hline Irrigation water applied (IWA) & $* *$ & $* *$ & $* *$ & $* *$ & $* *$ \\
\hline $\mathrm{I}_{100 \%}$ & $110.6 \pm 1.3^{\mathrm{a}}$ & $22.1 \pm 0.91^{\mathrm{a}}$ & $5.6 \pm 0.24^{b}$ & $59.3 \pm 1.8^{\mathrm{a}}$ & $169.1 \pm 5.3^{\mathrm{a}}$ \\
\hline $\mathrm{I}_{80 \%}$ & $105.8 \pm 1.4^{\mathrm{b}}$ & $20.9 \pm 0.73^{a, b}$ & $5.9 \pm 0.07^{\mathrm{a}}$ & $60.4 \pm 3.7^{\mathrm{a}}$ & $168.9 \pm 7.0^{\mathrm{a}}$ \\
\hline $\mathrm{I}_{60 \%}$ & $97.5 \pm 1.7^{c}$ & $19.8 \pm 0.53^{b}$ & $4.5 \pm 0.31^{\mathrm{c}}$ & $56.5 \pm 1.2^{b}$ & $169.1 \pm 4.1^{b}$ \\
\hline ACBio & $* *$ & $* *$ & $* *$ & $* *$ & $* *$ \\
\hline $\mathrm{ACBio}_{0}$ & $97.6 \pm 1.6^{\mathrm{c}}$ & $19.6 \pm 0.84^{b}$ & $4.4 \pm 0.33^{\mathrm{c}}$ & $51.4 \pm 1.9^{\mathrm{c}}$ & $152.0 \pm 6.8^{c}$ \\
\hline $\mathrm{ACBiO}_{5}$ & $106.7 \pm 1.3^{b}$ & $21.4 \pm 0.72^{\mathrm{a}}$ & $5.7 \pm 0.18^{b}$ & $58.0 \pm 1.8^{b}$ & $165.7 \pm 3.8^{b}$ \\
\hline $\mathrm{ACBio}_{10}$ & $109.7 \pm 1.7^{\mathrm{a}}$ & $21.8 \pm 0.63^{a}$ & $5.9 \pm 0.07^{\mathrm{a}}$ & $66.8 \pm 2.3^{a}$ & $180.4 \pm 3.5^{a}$ \\
\hline
\end{tabular}

** and * indicate respectively differences at $p \leq 0.05$ and $p \leq 0.01$ probability level, ns indicates not significant difference. Means followed by the same letter in each column are not significantly different according to the LSD test $(p<0.05)$. 
Table 6. Mean square, F value, and probability for plant height, leaf number, branch number, dry matter, and leaf area.

\begin{tabular}{|c|c|c|c|c|c|c|c|c|c|c|c|}
\hline \multirow[b]{2}{*}{ Items } & \multirow[b]{2}{*}{ df } & \multicolumn{5}{|c|}{ Mean Square } & \multicolumn{5}{|c|}{ F Value and Probability } \\
\hline & & $\begin{array}{c}\text { Plant } \\
\text { Height } \\
\text { (cm) }\end{array}$ & $\begin{array}{l}\text { Leave } \\
\text { No. }\end{array}$ & $\begin{array}{c}\text { Branch } \\
\text { No. }\end{array}$ & $\begin{array}{c}\text { Dry } \\
\text { Matter }\end{array}$ & $\begin{array}{l}\text { Leave } \\
\text { Area } \\
\left(\mathrm{dm}^{2}\right)\end{array}$ & $\begin{array}{c}\text { Plant } \\
\text { Height } \\
(\mathrm{cm})\end{array}$ & $\begin{array}{c}\text { Leave } \\
\text { No. }\end{array}$ & $\begin{array}{c}\text { Branch } \\
\text { No. }\end{array}$ & $\begin{array}{c}\text { Dry } \\
\text { Matter }\end{array}$ & $\begin{array}{c}\text { Leave } \\
\text { Area } \\
\left(\mathrm{dm}^{2}\right)\end{array}$ \\
\hline Season $(S)$ & 1 & 200.3 & 75.9 & 2.5 & 742.2 & 5329.31 & $50.4^{\mathrm{ns}}$ & $18.8^{\mathrm{ns}}$ & $28.1^{\mathrm{ns}}$ & $271.7 *$ & $18.42 *$ \\
\hline IWA & 2 & 791.4 & 24.5 & 11.8 & 70.6 & 464.06 & $199.2 *$ & $6.1 *$ & $133.6 *$ & $25.9 *$ & $27.63 *$ \\
\hline ACBio & 2 & 716.1 & 25.9 & 9.2 & 1079.6 & 3623.95 & $180.3 *$ & $6.4^{*}$ & $103.5 *$ & $395.2 *$ & $44.23 *$ \\
\hline $\mathrm{S} \times \mathrm{IWA}$ & 2 & 11.5 & 17.9 & 0.09 & 178.9 & 854.82 & $2.9^{\mathrm{ns}}$ & $4.4^{*}$ & $0.99 \mathrm{~ns}$ & $65.0 *$ & $50.89 *$ \\
\hline $\mathrm{S} \times \mathrm{ACBio}$ & 2 & 26.7 & 4.9 & 0.002 & 177.5 & 4582.64 & $6.7^{*}$ & $1.2^{\mathrm{ns}}$ & $0.02^{\mathrm{ns}}$ & $65.5 *$ & $55.93 *$ \\
\hline $\mathrm{IWA} \times$ ACBio & 4 & 15.3 & 27.8 & 8.1 & 327.6 & 581.04 & $3.8^{*}$ & $6.9 *$ & $91.5 *$ & $119.9 *$ & 7.09 * \\
\hline $\begin{array}{c}\mathrm{S} \times \mathrm{IWA} \times \\
\mathrm{ACBio}\end{array}$ & 4 & 29.8 & 15.2 & 0.1 & 174.3 & 106.07 & $7.5^{*}$ & $3.8 *$ & $0.75^{\mathrm{ns}}$ & $63.8 *$ & $1.29 \mathrm{~ns}$ \\
\hline Exp. error & 24 & 4.0 & 4.0 & 0.1 & 2.7 & 81.94 & & & & & \\
\hline
\end{tabular}

ns: Nonsignificant. * Significant at the $p \leq 0.05$ level.

In this concern, [61,62] stated that biochar may improve the productivity of legume crops due to the increasing biological $\mathrm{N}_{2}$ fixation. In general, our findings confirmed the potential effect of ACBio utilization in improving faba bean performance under abiotic stress. Various studies provided many hypotheses to indicate the influence of biochar addition on plant growth. In this context, [63] concluded that the use of biochar in some legumes crops increased shoot length, dry matter, nutrient concentration, and yield.

\subsection{Water Productivity and Irrigation-Water Use Efficiency}

Results presented in Table 7 and 8 reveal that WP and I-WUE were strongly affected by irrigation and ACBio treatments. On the other hand, the differences between growing seasons were significant for WP and non-significant for I-WUE. The WP and I-WUE's values were 11.9 and 15.6 for $S_{I}$, and 11.5 and $14.9 \mathrm{~kg} \mathrm{~mm}^{-1}$ for $\mathrm{S}_{\text {II }}$ (Table 7). Likewise, the interactions between the irrigation regime and acidified biochar or between the irrigation regime, ACBio, and growing seasons were significantly affected (Table 8). Regarding the influence of IWA, results indicated that the values of WP and I-WUE were 10.5 and 14.2 for $\mathrm{I}_{100 \%}, 12.1$ and 15.7 for $\mathrm{I}_{80 \%}$, and 12.2 and $15.8 \mathrm{~kg} \mathrm{~mm}^{-1}$ for $\mathrm{I}_{60 \%}$, demonstrating that the WP and I-WUE for $\mathrm{I}_{60} \%$ was higher by 15.2 and 10.6 than those of $\mathrm{I}_{80 \%}$ and by 16.2 and $11.3 \%$ for $\mathrm{I}_{100 \%}$, respectively (Table 7). These outcomes are in concurrence with those of [11,64-69] who reported that I-WUE was not increased with increasing irrigation quantity for sorghum and melon.

Table 7. Means and standard errors for pod number, pod weight plant ${ }^{-1}, 100$ seed weight, seed yield, water productivity (WP), and irrigation water use efficiency (I-WUE).

\begin{tabular}{|c|c|c|c|c|c|c|}
\hline \multirow[b]{2}{*}{ Items } & \multicolumn{6}{|c|}{ Mean \pm SE } \\
\hline & $\begin{array}{l}\text { Pods No. } \\
\text { Plant }^{-1}\end{array}$ & $\begin{array}{l}\text { Pods Weight } \\
\text { Plant }^{-1} \text { (g) }\end{array}$ & $\begin{array}{c}100 \text { Seed } \\
\text { Weight (g) }\end{array}$ & $\begin{array}{l}\text { Seed Yield } \\
\left(t \mathrm{ha}^{-1}\right)\end{array}$ & $\begin{array}{c}W P \\
\left(\mathrm{~kg} \mathrm{~mm}^{-1}\right)\end{array}$ & $\begin{array}{c}\text { I-WUE } \\
\left(\mathrm{Kg} \mathrm{mm}^{-1}\right)\end{array}$ \\
\hline Years & NS & NS & NS & NS & NS & * \\
\hline $\mathrm{S}_{\mathrm{I}}$ & $32.6 \pm 1.00 \mathrm{a}$ & $127.8 \pm 5.30 \mathrm{a}$ & $71.5 \pm 1.6 \mathrm{a}$ & $3.7 \pm 0.17 \mathrm{a}$ & $11.9 \pm 0.05 \mathrm{a}$ & $15.6 \pm 0.05 \mathrm{a}$ \\
\hline $\mathrm{S}_{\mathrm{II}}$ & $34.8 \pm 1.30 \mathrm{a}$ & $124.1 \pm 6.70 \mathrm{a}$ & $68.4 \pm 1.6 \mathrm{a}$ & $3.7 \pm 0.19 \mathrm{a}$ & $11.5 \pm 0.05 \mathrm{a}$ & $14.9 \pm 0.05 \mathrm{a}$ \\
\hline Irrigation water applied (IWA) & * & $* *$ & $* *$ & $* *$ & $* *$ & $* *$ \\
\hline $\mathrm{I}_{100 \%}$ & $34.7 \pm 1.30 \mathrm{a}$ & $150.0 \pm 5.70 \mathrm{a}$ & $71.2 \pm 1.4 \mathrm{a}$ & $4.3 \pm 0.22 \mathrm{a}$ & $10.5 \pm 0.05 \mathrm{~b}$ & $14.2 \pm 0.05 b$ \\
\hline $\mathrm{I}_{80 \%}$ & $34.6 \pm 1.70 \mathrm{a}$ & $132.8 \pm 3.90 \mathrm{~b}$ & $75.0 \pm 2.0 \mathrm{a}$ & $4.1 \pm 0.18 \mathrm{a}$ & $12.1 \pm 0.05 \mathrm{a}$ & $15.7 \pm 0.05 \mathrm{a}$ \\
\hline $\begin{array}{c}\mathrm{I}_{60 \%} \\
\text { ACBio }\end{array}$ & $\underset{* *}{31.7 \pm 1.30 \mathrm{~b}}$ & $\underset{* *}{95.1 \pm 5.20 c}$ & $\underset{* *}{63.6 \pm 1.5 b}$ & $\underset{* *}{3.2 \pm 0.16 b}$ & $\underset{* *}{12.2 \pm 0.06} \mathrm{a}$ & $\underset{* *}{15.8} \pm 0.06 \mathrm{a}$ \\
\hline $\mathrm{ACBio}_{0}$ & $28.1 \pm 0.88 c$ & $104.3 \pm 6.10 c$ & $65.2 \pm 2.0 \mathrm{~b}$ & $2.7 \pm 0.10 c$ & $9.5 \pm 0.01 \mathrm{c}$ & $12.3 \pm 0.01 \mathrm{c}$ \\
\hline $\mathrm{ACBiO}_{5}$ & $35.3 \pm 1.28 b$ & $128.7 \pm 5.50 b$ & $73.0 \pm 1.4 \mathrm{a}$ & $3.9 \pm 0.10 \mathrm{~b}$ & $12.2 \pm 0.03 \mathrm{~b}$ & $15.8 \pm 0.03 b$ \\
\hline ACBio $_{10}$ & $37.6 \pm 1.12 \mathrm{a}$ & $144.8 \pm 7.10 \mathrm{a}$ & $71.7 \pm 1.9 \mathrm{a}$ & $4.4 \pm 0.20 \mathrm{a}$ & $13.6 \pm 0.03 \mathrm{a}$ & $17.7 \pm 0.03 \mathrm{a}$ \\
\hline
\end{tabular}

** and * indicate respectively differences at $p \leq 0.05$ and $p \leq 0.01$ probability level, ns indicates not significant difference. Means followed by the same letter in each column are not significantly different according to the LSD test $(p<0.05)$. 
Table 8. Mean square, F value, and probability for pod number, pod weight plant $^{-1}, 100$ seed weight, seed yield, water productivity (WP), and irrigation water use efficiency (I-WUE).

\begin{tabular}{|c|c|c|c|c|c|c|c|c|c|c|c|c|c|}
\hline \multirow[b]{2}{*}{ Items } & \multirow[b]{2}{*}{ df } & \multicolumn{6}{|c|}{ Mean Square } & \multicolumn{6}{|c|}{ F Value and Probability } \\
\hline & & $\begin{array}{c}\text { Pods } \\
\text { No. }\end{array}$ & $\begin{array}{l}\text { Pods } \\
\text { Weight } \\
\text { Plant }^{-1} \\
\text { (g) }\end{array}$ & $\begin{array}{c}100 \\
\text { Seed } \\
\text { Weight } \\
\text { (g) }\end{array}$ & $\begin{array}{c}\text { Seed } \\
\text { Yield } \\
\left(\mathbf{t ~ h a}^{-1}\right)\end{array}$ & $\begin{array}{c}\text { WP } \\
(\mathrm{kg} \\
\left.\mathrm{mm}^{-1}\right)\end{array}$ & $\begin{array}{c}\text { I-WUE } \\
\left(\mathrm{kg}^{-1}\right) \\
\mathrm{mm}^{-1}\end{array}$ & $\begin{array}{c}\text { Pods } \\
\text { No. }\end{array}$ & $\begin{array}{l}\text { Pods } \\
\text { Weight } \\
\text { Plant }^{-1} \\
\text { (g) }\end{array}$ & $\begin{array}{c}100 \\
\text { Seed } \\
\text { Weight } \\
\text { (g) }\end{array}$ & $\begin{array}{c}\text { Seed } \\
\text { Yield } \\
\left(\mathrm{t} \mathrm{ha}^{-1}\right)\end{array}$ & $\begin{array}{c}\text { WP } \\
(\mathrm{kg} \\
\left.\mathrm{mm}^{-1}\right)\end{array}$ & $\begin{array}{c}\text { I-WUE } \\
\left(\mathrm{kg}^{-1}\right) \\
\mathrm{mm}^{-1}\end{array}$ \\
\hline Season (S) & 1 & 66.4 & 189.7 & 139.84 & 0.04 & 2.65 & 5.84 & $6.63^{\mathrm{ns}}$ & $5.02^{\mathrm{ns}}$ & $6.78^{\mathrm{ns}}$ & $0.78^{\mathrm{ns}}$ & $3.62^{\text {ns }}$ & $4.8 *$ \\
\hline IWA & 2 & 54.0 & 14162.9 & 607.88 & 7.17 & 9.03 & 14.5 & 10.12 * & $134.23 *$ & 12.31 * & $77.8 *$ & 12.4 * & 11.8 * \\
\hline ACBio & 2 & 448.4 & 7476.1 & 311.98 & 13.93 & 78.78 & 132.5 & $48.5 *$ & $69.93 *$ & $9.35 *$ & $297.3 *$ & $107.8 *$ & 107.9 * \\
\hline$S \times I W A$ & 2 & 104.2 & 529.0 & 93.28 & 0.05 & 1.63 & 2.6 & $19.5 *$ & $5.0 *$ & $1.89^{\mathrm{ns}}$ & $0.6^{\mathrm{ns}}$ & $2.23^{\mathrm{ns}}$ & $2.1^{\mathrm{ns}}$ \\
\hline $\mathrm{S} \times$ ACBio & 2 & 16.1 & 12.3 & 71.41 & 0.03 & 0.01 & 0.01 & $1.74^{\mathrm{ns}}$ & $0.11^{\mathrm{ns}}$ & $2.14^{\mathrm{ns}}$ & $0.56^{\mathrm{ns}}$ & $0.01^{\mathrm{ns}}$ & $0.01^{\mathrm{ns}}$ \\
\hline $\begin{array}{l}\text { IWA } \times \\
\text { ACBio }\end{array}$ & 4 & 54.1 & 236.1 & 17.54 & 0.15 & 6.01 & 10.2 & $5.86 *$ & $2.21^{\mathrm{ns}}$ & $0.53^{\mathrm{ns}}$ & $3.14 *$ & $8.3 *$ & $8.3 *$ \\
\hline $\begin{array}{c}\mathrm{S} \times \mathrm{IWA} \times \\
\mathrm{ACBio}\end{array}$ & 4 & 48.9 & 503.1 & 6.84 & 0.27 & 2.6 & 4.4 & $5.3 *$ & 4.71 * & $0.20^{\mathrm{ns}}$ & $5.69 *$ & $3.6^{*}$ & $3.6^{*}$ \\
\hline Exp. error & 24 & 9.2 & 106.9 & 33.36 & 0.05 & 0.73 & 1.2 & & & & & & \\
\hline
\end{tabular}

ns: Nonsignificant. * Significant at the $p \leq 0.05$ level.

According to Figure 3, the correlation between IWA and I-WUE was curvilinear and the following equations indicate this relation:

$$
\begin{gathered}
\mathrm{I}-\mathrm{WUE}=-8 \times 10^{-5} \times \mathrm{IWA}^{2}+0.0244 \times \mathrm{IWA}+14.97, \mathrm{R}^{2}=0.781, \\
\mathrm{I} \text {-WUE }=-0.0003 \times \mathrm{IWA}^{2}+0.1284 \times \mathrm{IWA}+0.0889, \mathrm{R}^{2}=0.652 .
\end{gathered}
$$

Results presented in Table 7 show that WP and I-WUE were influenced positively $(p \leq 0.05)$ via the addition of ACBio. The maximum values of WP and I-WUE (13.6 and $17.7 \mathrm{~kg} \mathrm{~mm}^{-1}$ ) were observed in $\mathrm{ACBio}_{10}$ compared to 12.2 and 15.8 for $\mathrm{ACBio}_{5}$ and 9.48 and $12.3 \mathrm{~kg} \mathrm{~mm}^{-1}$ for $\mathrm{ACBio}_{0}$, respectively. By increasing the addition of ACBio from 0 to 5 and $10 \mathrm{t} \mathrm{ha}^{-1}$ of ACBio, WP values were increased by 28.7 and $43.5 \%$, while I-WUE values were increased by 28.5 and $44 \%$, respectively. Acidified biochar additions improve physico-chemical soil properties (Table 3) and mineral uptake (Table 4). Moreover, RACio improved water relations, as well as growth and yield relative to control (Tables 6 and 7). All of these factors are mainly responsible for improving WP and I-WUE. These findings are similar to those of $[65,66]$. 

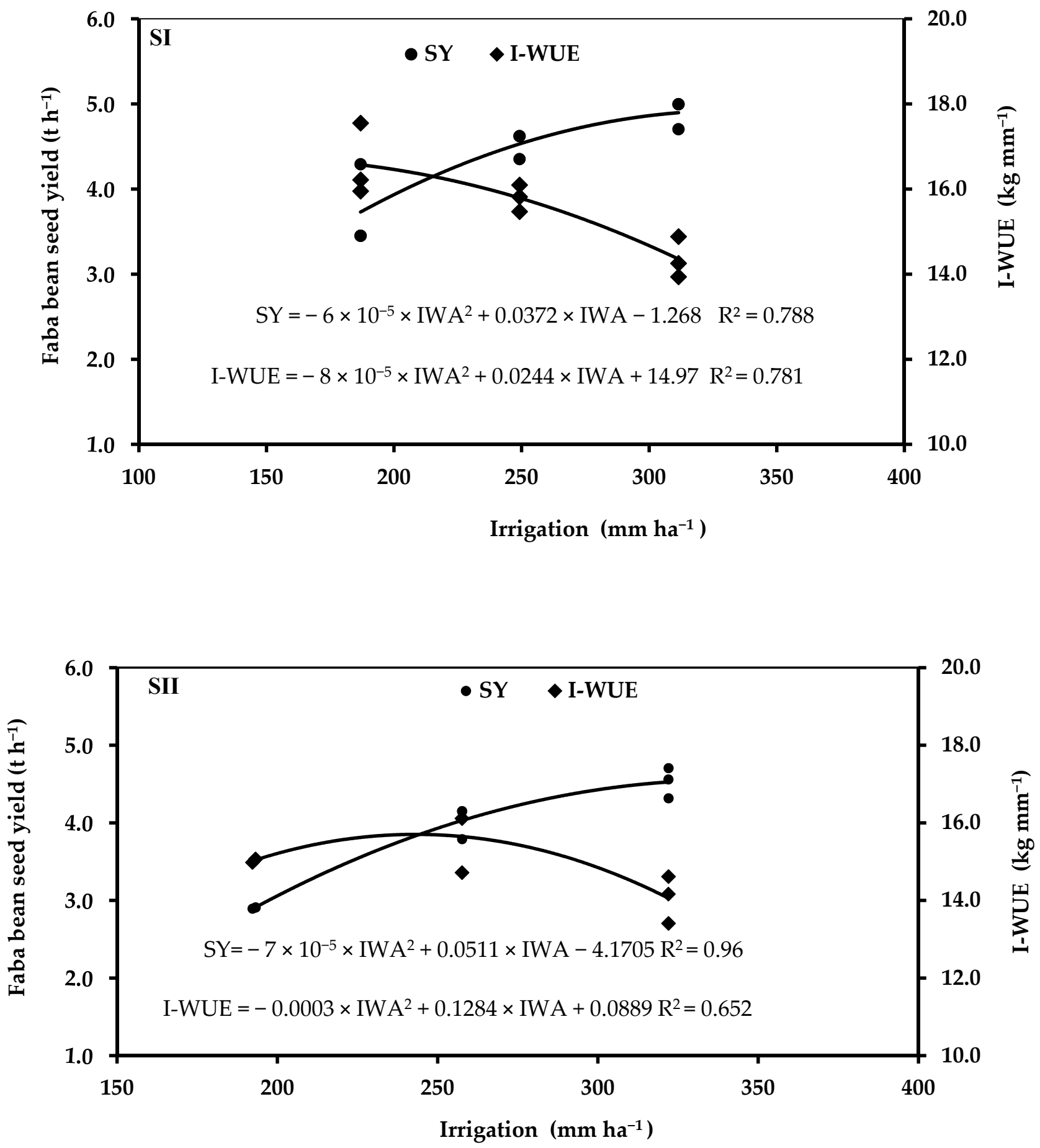

Figure 3. Regression analysis between irrigation water applied (IWA), faba bean seed yield (SY), and irrigation-water use efficiency (I-WUE) in $\mathrm{S}_{\mathrm{I}}(2016 / 17)$ and $\mathrm{S}_{\mathrm{II}}(2017 / 18)$ seasons.

\subsection{Faba Bean Seeds Yield}

Pods number, pods weight, weight of 100 seeds, and seed yield $\left(\mathrm{t} \mathrm{ha}{ }^{-1}\right)$ were analyzed statistically and presented in Tables 7 and 8 . They were positively influenced by IWA and ACBio rate and not affected by seasons $(p \leq 0.05)$. Except for the pod number and weight of pods, no differences were observed for the interaction between irrigation and seasons (Table 8). Except for the pod number and seeds yield, the interaction between irrigation and ACBio for the aforementioned traits was not significant. The maximum seeds yield (4.9 and $5.5 \mathrm{t} \mathrm{ha}^{-1}$ for $\mathrm{S}_{\mathrm{I}}$ and $\mathrm{S}_{\mathrm{II}}$ ) were observed when faba bean plants were 
exposed to $\mathrm{I}_{100 \%}$ combined with $10 \mathrm{tha}^{-1}$ of ACBio. Conversely, the lowest seeds yield was recorded under severe irrigation conditions $\left(\mathrm{I}_{60}\right)$ without ACBio. Referring to the impact of irrigation regimes, findings showed that irrigated plants at $\mathrm{I}_{100 \%}$ increased faba bean seeds yield significantly followed by $\mathrm{I}_{80} \%$ during both growing seasons. The highest yield was $\left(4.33 \mathrm{tha}^{-1}\right)$ recorded when the faba bean received $\mathrm{I}_{100 \%}$ of ETc, whereas the lowest seeds yield was $3.16 \mathrm{t} \mathrm{ha}^{-1}$ observed under $\mathrm{I}_{60 \%}$ treatment (Table 7). A severe irrigation regime ( $\mathrm{I}_{60} \%$ of ETc) sharply reduced seeds yield by $37 \%$ and $30.4 \%$, compared with $\mathrm{I}_{100 \%}$ and $\mathrm{I}_{80 \%}$ as an average for $\mathrm{S}_{\mathrm{I}}$ and $\mathrm{S}_{\mathrm{II}}$, respectively. These findings may be due to the sufficient availability of soil moisture content, which leads to an increase in plant water status, physiological responses, increased activity of the microbial soil, improved nutrients uptake, and enhanced rates of photosynthesis, which may reflect on growth traits, pod number, pods weight, 100 seeds weight, and consequently higher yield. Similar outcomes were detected by $[67,68]$. Figure 3 shows the relationship between IWA and faba bean seed yield (SY) for $\mathrm{S}_{\mathrm{I}}$ and $\mathrm{S}_{\mathrm{II}}$ (polynomial of 2 nd order). The relationship could be shown as follows:

$$
\begin{aligned}
& \mathrm{SY}=-6 \times 10^{-5} \times \mathrm{IWA}^{2}+0.0372 \times \mathrm{IWA}-1.268, \mathrm{R}^{2}=0.788 \\
& \mathrm{SY}=-7 \times 10^{-5} \times \mathrm{IWA}^{2}+0.0511 \times \mathrm{IWA}-4.1705, \mathrm{R}^{2}=0.96
\end{aligned}
$$

Regarding the impact of ACBio on the yield and quality of faba bean, data in Table 7 and 8 reflected that the highest yield was enlisted via the utilization of $A C B i 0_{10}$. Results showed that the utilization of $\mathrm{ACBio}_{10}$ or $\mathrm{ACBio}_{5}$ increased the yield of faba bean by 53.94 and $32.78 \%$ compared to $\mathrm{ACBio}_{0}$. The effect of acidified biochar as a soil amendment on faba bean seeds yield was more significant under water stress. Similar findings were observed by [70-74]. Thus, merging deficit irrigation and acidified biochar could be the best strategy to increase the seeds yield of faba bean under water shortage. According to the analysis of ACBio (Table 2), it has a great organic carbon percentage, ash, macro and micronutrients, and cation exchange capacity (CEC). These ingredients enhance the acidified biochar in favor of the growing faba bean by modulating soil properties (hydrophysical, (i.e., total porosity, bulk density and field capacity) and chemical (i.e., ECe, $\mathrm{pH}$, $\mathrm{OM} \%$, and macronutrients)). Moreover, the addition of ACBio increased the macronutrients (N, P, K, and Ca) concentration (Table 4) in faba bean plants. Subsequently, the content of nutrients will increase and easily uptake by growing faba bean plants, leading to an obvious increase in the growing and production of faba bean. This might be possibly interpreted by the positive role of ACBio on the soil properties; reduce soil $\mathrm{pH}$, increase field capacity, total porosity, $\mathrm{OM} \%$, and nutrients uptake resulted in increasing the growth and productivity of faba bean.

\section{Conclusions}

Water restriction significantly reduced faba bean water status, physiological attributes, growth, and seeds yield of faba bean crop. Results showed that suppling ACBio was effective in modifying the adversative impacts of water scarcity through enhancing the quantum efficiency of a photosystem, water status, I-WUE, soil microbial activity, SPAD value, plant growth attributes, and improving soil properties. In this concern, ACBio could reduce bulk density, $\mathrm{pH}, \mathrm{ECe}$, and increase field capacity, soil macronutrients content $(\mathrm{N}, \mathrm{P}$, and $\mathrm{K}$ ), and $\mathrm{OM} \%$. It could be stated that $\mathrm{I}_{100}+\mathrm{ACBio}_{10}$ was more suitable for obtaining the maximum seed yield in abiotic stress. Under limited water resources, a combination of $\mathrm{I}_{80 \%}$ and $10 \mathrm{tha}^{-1}$ ACBio is highly recommended to attain optimal seed yield with the opportunity of saving $20 \%$ of irrigation water during faba bean growing season.

Author Contributions: Conceptualization, T.A.A.E.-M., M.O.A.R., E.E.B., S.A.A.E.-M., and W.M.S. methodology, T.A.A.E.-M., M.O.A.R., E.E.B., S.A.A.E.-M., and W.M.S.; software, T.A.A.E.-M., M.O.A.R., E.E.B., S.A.A.E.-M., and W.M.S.; validation, T.A.A.E.-M., M.O.A.R., E.E.B., S.A.A.E.-M., and W.M.S.; formal analysis, T.A.A.E.-M., M.O.A.R., E.E.B., S.A.A.E.-M., and W.M.S.; investigation, T.A.A.E.-M., M.O.A.R., E.E.B., S.A.A.E.-M., and W.M.S.; data curation, T.A.A.E.-M., M.O.A.R., E.E.B., S.A.A.E.- 
M., and W.M.S., writing-original draft preparation, T.A.A.E.-M., M.O.A.R., E.E.B., E.M., M.F.A., S.A.A.E.-M., and W.M.S.; writing-review and editing, T.A.A.E.-M., M.O.A.R., E.E.B., E.M., M.F.A., S.A.A.E.-M., and W.M.S.; visualization, T.A.A.E.-M., M.O.A.R., and W.M.S.; supervision, T.A.A.E.-M., M.O.A.R., and E.E.B.; funding acquisition, T.A.A.E.-M., M.O.A.R., and W.M.S., All authors have read and agreed to the published version of the manuscript.

Funding: This research received no external funding.

Institutional Review Board Statement: Not applicable.

Informed Consent Statement: Not applicable.

Data Availability Statement: The data presented in this study are available upon request from the corresponding author.

Acknowledgments: The authors extend their appreciation to Taif University for funding this work through Taif University Researchers Supporting Project, number TURSP-2020/111, Taif University, Taif, Saudi Arabia.

Conflicts of Interest: The authors declare no conflict of interest.

\section{References}

1. Cazzato, E.; Tufarelli, V.; Ceci, E.; Stellacci, A.M.; Laudadio, V. Quality, yield and nitrogen fixation of faba bean seeds as affected by sulphur fertilization. Acta Agric. Scand. Sect. B Soil Plant Sci. 2012, 62, 732-738. [CrossRef]

2. Nachi, N.; Le Guen, J. Dry matter accumulation and seed yield in faba bean (Vicia faba L.) genotypes. Agronomie 1996, 16, 47-59. [CrossRef]

3. Burbano, C.; Cuadrado, C.; Muzquiz, M.; Cubero, J.I. Variation of favism-inducing factors (vicine, convicine and L-DOPA) during pod development in Vicia faba L. Plant Foods Hum. Nutr. 1995, 47, 265-274. [CrossRef] [PubMed]

4. Zeidan, M.S. Effect of sowing dates and urea foliar application on growth and seed yield of determinate faba bean (Vicia faba L.) under Egyptian conditions. J. Agron. 2003, 24, 93-102.

5. Min, W.; Guo, H.J.; Zhang, W.; Zhou, G.W.; Ma, L.J.; Ye, J.; Hou, Z.A. Irrigation water salinity and N fertilization: Effects on ammonia oxidizer abundance, enzyme activity and cotton growth in a drip irrigated cotton field. J. Integr. Agric. 2016, 15, 1121-1131. [CrossRef]

6. Pereira, L.S.; Cordery, I.; Iacovides, I. Improved indicators of water use performance and productivity for sustainable water conservation and saving. Agric. Water Manag. 2012, 108, 39-51. [CrossRef]

7. Abd El-Mageed, T.A.; Abdelkhalik, A.; Abd El-Mageed, S.A.; Semida, W.M. Co-composted poultry litter biochar enhanced soil quality and eggplant productivity under different irrigation regimes. J. Soil Sci. Plant Nutr. 2021, 1-17. [CrossRef]

8. Semida, W.M.; Abdelkhalik, A.; Mohamed, G.F.; Abd El-Mageed, T.A.; Abd El-Mageed, S.A.; Rady, M.M.; Ali, E.F. Foliar Application of Zinc Oxide Nanoparticles Promotes Drought Stress Tolerance in Eggplant (Solanum melongena L.). Plants 2021, 10, 421. [CrossRef] [PubMed]

9. Rady, M.O.A.; Semida, W.M.; Howladar, S.M.; Taia, A. Abd El-Mageed Raised beds modulate physiological responses, yield and water use efficiency of wheat (Triticum aestivum L) under deficit irrigation. Agric. Water Manag. 2021, 245, 106629. [CrossRef]

10. Badal, E.; El-Mageed, T.A.A.; Buesa, I.; Guerra, D.; Bonet, L.; Intrigliolo, D.S. Moderate plant water stress reduces fruit drop of "Rojo Brillante" persimmon (Diospyros kaki) in a Mediterranean climate. Agric. Water Manag. 2013, 119, 154-160. [CrossRef]

11. El- Samnoudi, I.M.; Ibrahim, A.E.-A.M.; Abd El Tawwab, A.R.; Abd El-Mageed, T.A. Combined Effect of Poultry Manure and Soil Mulching on Soil Properties, Physiological Responses, Yields and Water-use Efficiencies of Sorghum Plants under Water Stress. Commun. Soil Sci. Plant Anal. 2019, 50. [CrossRef]

12. Agami, R.A.; Alamri, S.A.M.; Abd El-Mageed, T.A.; Abousekken, M.S.M.; Hashem, M. Salicylic acid and proline enhance water use efficiency, antioxidant defense system and tissues' anatomy of wheat plants under field deficit irrigation stress. J. Appl. Bot. Food Qual. 2019, 92, 360-370. [CrossRef]

13. Moustafa, E.S.A.; Ali, M.M.A.; Kamara, M.M.; Awad, M.F.; Hassanin, A.A.; Mansour, E. Field screening of wheat advanced lines for salinity tolerance. Agronomy 2021, 11, 281. [CrossRef]

14. Semida, W.M.; Beheiry, H.R.; Sétamou, M.; Simpson, C.R.; Abd El-Mageed, T.A.; Rady, M.M.; Nelson, S.D. Nelson Biochar implications for sustainable agriculture and environment: A review. S. Afr. J. Bot. 2019, 127, 333-347. [CrossRef]

15. Abd El-Mageed, T.A.; Rady, M.M.; Taha, R.S.; Abd El Azeam, S.; Simpson, C.R.; Semida, W.M. Effects of integrated use of residual sulfur-enhanced biochar with effective microorganisms on soil properties, plant growth and short-term productivity of Capsicum annuum under salt stress. Sci. Hortic. 2020, 261, 108930. [CrossRef]

16. Abd El-Mageed, T.A.; Abdurrahman, H.A.; Abd El-Mageed, S.A. Residual acidified biochar modulates growth, physiological responses, and water relations of maize (Zea mays) under heavy metal-contaminated irrigation water. Environ. Sci. Pollut. Res. 2020, 27, 22956-22966. [CrossRef] [PubMed]

17. Man, Y.; Wang, B.; Wang, J.; Slaný, M.; Yan, H.; Li, P. Use of biochar to reduce mercury accumulation in Oryza sativa L.: A trial for sustainable management of historically polluted farmlands. Environ. Int. 2021, 153, 106527. [CrossRef] 
18. Wang, Q.; Shaheen, S.M.; Jiang, Y.; Li, R.; Slaný, M.; Hamada Abdelrahman, E.K.; Bolan, N.; Rinklebe, J.; Zhang, Z. Fe/Mn- and $\mathrm{P}$-modified drinking water treatment residuals reduced $\mathrm{Cu}$ and $\mathrm{Pb}$ phytoavailability and uptake in a mining soil. J. Hazard. Mater. 2021, 403, 123628. [CrossRef]

19. Moustafa, E.S.A.; El-Sobky, E.-S.E.A.; Farag, H.I.A.; Yasin, M.A.T.; Attia, A.; Rady, M.O.A.; Awad, M.F.; Mansour, E. Sowing Date and Genotype Influence on Yield and Quality of Dual-Purpose Barley in a Salt-Affected Arid Region. Agronomy 2021, 11, 717. [CrossRef]

20. Hafez, Y.; Attia, K.; Alamery, S.; Ghazy, A.; Al-Doss, A.; Ibrahim, E.; Rashwan, E.; El-Maghraby, L.; Awad, A.; Abdelaal, K. Beneficial effects of biochar and chitosan on antioxidative capacity, osmolytes accumulation, and anatomical characters of water-stressed barley plants. Agronomy 2020, 10, 630. [CrossRef]

21. Akhtar, S.; Andersen, M.N.; Liu, F. Residual effects of biochar on improving growth, physiology and yield of wheat under salt stress. Agric. Water Manag. 2015, 158, 61-68. [CrossRef]

22. Akhtar, S.S.; Li, G.; Andersen, M.N.; Liu, F. Biochar enhances yield and quality of tomato under reduced irrigation. Agric. Water Manag. 2014, 138, 37-44. [CrossRef]

23. Liang, C.; Zhu, X.; Fu, S.; Méndez, A.; Gascó, G.; Paz-Ferreiro, J. Biochar alters the resistance and resilience to drought in a tropical soil. Environ. Res. Lett. 2014, 9, 064013. [CrossRef]

24. Rady, M.M.; Taha, R.S.; Semida, W.M.; Alharby, H.F. Modulation of salt stress effects on vicia faba 1. plants grown on a reclaimed-saline soil by salicylic acid application. Rom. Agric. Res. 2017, 34, 175-185.

25. Fornes, F.; Belda, R.M. Use of raw and acidified biochars as constituents of growth media for forest seedling production. New For. 2019, 50, 1063-1086. [CrossRef]

26. Ur Rehman, M.Z.; Batool, Z.; Ayub, M.A.; Hussaini, K.M.; Murtaza, G.; Usman, M.; Naeem, A.; Khalid, H.; Rizwan, M.; Ali, S. Effect of acidified biochar on bioaccumulation of cadmium $(\mathrm{Cd})$ and rice growth in contaminated soil. Environ. Technol. Innov. 2020, 19, 101015. [CrossRef]

27. Ramzani, P.M.A.; Shan, L.; Anjum, S.; Ronggui, H.; Iqbal, M.; Virk, Z.A.; Kausar, S. Improved quinoa growth, physiological response, and seed nutritional quality in three soils having different stresses by the application of acidified biochar and compost. Plant Physiol. Biochem. 2017, 116, 127-138. [CrossRef]

28. Lehmann, J.; Gaunt, J.; Rondon, M. Bio-char sequestration in terrestrial ecosystems-A review. Mitig. Adapt. Strateg. Glob. Chang. 2006, 11, 403-427. [CrossRef]

29. Lehmann, J.; Pereira da Silva, J.; Steiner, C.; Nehls, T.; Zech, W.; Glaser, B. Nutrient availability and leaching in an archaeological Anthrosol and $\mathrm{a} \backslash$ rFerralsol of the Central Amazon basin: Fertilizer, manure and charcoal $\backslash$ ramendments. Plant Soil 2003, 249, 343-357. [CrossRef]

30. Steiner, C.; Teixeira, W.G.; Lehmann, J.; Nehls, T.; De MacÊdo, J.L.V.; Blum, W.E.H.; Zech, W. Long term effects of manure, charcoal and mineral fertilization on crop production and fertility on a highly weathered Central Amazonian upland soil. Plant Soil 2007, 291, 275-290. [CrossRef]

31. Van Zwieten, L.; Kimber, S.; Downie, A.; Morris, S.; Petty, S.; Rust, J.; Chan, K.Y. A glasshouse study on the interaction of low mineral ash biochar with nitrogen in a sandy soil. Aust. J. Soil Res. 2010, 48, 569-576. [CrossRef]

32. Yuan, J.H.; Xu, R.K. The amelioration effects of low temperature biochar generated from nine crop residues on an acidic Ultisol. Soil Use Manag. 2011, 27, 110-115. [CrossRef]

33. Abd-Alla, M.H.; El-Enany, A.W.E.; Nafady, N.A.; Khalaf, D.M.; Morsy, F.M. Synergistic interaction of Rhizobium leguminosarum bv. viciae and arbuscular mycorrhizal fungi as a plant growth promoting biofertilizers for faba bean (Vicia faba L.) in alkaline soil. Microbiol. Res. 2014, 169, 49-58. [CrossRef]

34. Van Zwieten, L.; Kimber, S.; Morris, S.; Chan, K.Y.; Downie, A.; Rust, J.; Joseph, S.; Cowie, A. Effects of biochar from slow pyrolysis of papermill waste on agronomic performance and soil fertility. Plant Soil 2010, 327, 235-246. [CrossRef]

35. Clark, J.S. The pH Values of Soils Suspended in Dilute Salt Solutions. Soil Sci. Soc. Am. J. 1966, 30, 11-14. [CrossRef]

36. Chen, L.; Yin, H.; Xu, J.; Liu, X. Enhanced antioxidative responses of a salt-resistant wheat cultivar facilitate its adaptation to salt stress. Afr. J. Biotechnol. 2011, 10, 16887-16896. [CrossRef]

37. Lynch, J.P.; Clair, S.B.S. Mineral stress: The missing link in understanding how global climate change will affect plants in real world soils. Field Crop. Res. 2004, 90, 101-115. [CrossRef]

38. Chan, K.Y.; Van Zwieten, L.; Meszaros, I.; Downie, A.; Joseph, S. Agronomic values of greenwaste biochar as a soil amendment. Aust. J. Soil Res. 2007, 45, 629-634. [CrossRef]

39. Uchimiya, M.; Wartelle, L.H.; Klasson, K.T.; Fortier, C.A.; Lima, I.M. Influence of pyrolysis temperature on biochar property and function as a heavy metal sorbent in soil. J. Agric. Food Chem. 2011, 59, 2501-2510. [CrossRef] [PubMed]

40. Bell, M.J.; Worrall, F. Worrall Charcoal addition to soils in NE England: A carbon sink with environmental co-benefits? Sci. Total Environ. 2011, 409, 1704-1714. [CrossRef]

41. Ponce, V.M.; Pandey, R.P.; Ercan, S. Characterization of Drought Across Climatic Spectrum. J. Hydrol. Eng. ASCE 2000, 5, 222-224. [CrossRef]

42. Klute, A.; Dirksen, C. Hydraulic conductivity and diffusivity: Laboratory methods. In Methods of Soil Analysis: Part 1-Physical and Mineralogical Methods; Soil Science Society of America, American Society of Agronomy: Madison, WI, USA, 1986; Volume 9, pp. 687-734. 
43. Page, A.L.; Miller, R.H.; Keeney, D.R. Methods of Soil Analysis Part 2. Chemical and Microbiological Properties; American Society of Agronomy, Inc.: Madison, WI, USA, 1982.

44. Allen, R.G. FAO Irrigation and Drainage Paper Crop by. Irrig. Drain. 1998, 300, 300. [CrossRef]

45. Maxwell, K.; Johnson, G.N. Chlorophyll fluorescence-A practical guide. J. Exp. Bot. 2000, 51, 659-668. [CrossRef]

46. Clark, A.J.; Landolt, W.; Bucher, J.B.; Strasser, R.J. Beech (Fagus sylvatica) response to ozone exposure assessed with a chlorophyll a fluorescence performance index. Environ. Pollut. 2000, 109, 501-507. [CrossRef]

47. Premachandra, G.S.; Saneoka, H.; Ogata, S. Cell membrane stability, an indicator of drought tolerance, as affected by applied nitrogen in soyabean. J. Agric. Sci. 1990, 115, 63-66. [CrossRef]

48. Hayat, S.; Ali, B.; Hasan, S.A.; Ahmad, A. Brassinosteroid enhanced the level of antioxidants under cadmium stress in Brassica juncea. Environ. Exp. Bot. 2007, 60, 33-41. [CrossRef]

49. Jackson, M.L. Soil Chemical Analysis; Prentice Hall India Pvt. Ltd.: New Delhi, India, 1973.

50. Gomez, K.A.; Gomez, A.A. Statistical Procedures for Agricultural Research; John Wiley Sons Inc.: Hoboken, NJ, USA, 1984; pp. 20-212.

51. Widowati, W.H.; Guritno, B.; Soehono, L.A. The Effect of Biochar on the Growth and N Fertilizer Requirement of Maize (Zea mays L.) in Green House Experiment. J. Agric. Sci. 2012, 4, 255-262. [CrossRef]

52. Chintala, R.; Mollinedo, J.; Schumacher, T.E.; Malo, D.D.; Julson, J.L. Effect of biochar on chemical properties of acidic soil. Arch. Agron. Soil Sci. 2014, 60, 393-404. [CrossRef]

53. Abd El-Mageed, T.A.; El-Sherif, A.M.A.; Abd El-Mageed, S.A.; Abdou, N.M. A novel compost alleviate drought stress for sugar beet production grown in Cd-contaminated saline soil. Agric. Water Manag. 2019, 226, 105831. [CrossRef]

54. Laird, D.A. The charcoal vision: A win-win-win scenario for simultaneously producing bioenergy, permanently sequestering carbon, while improving soil and water quality. Agron. J. 2008, 100, 178-181. [CrossRef]

55. Paradelo, R.; Vázquez-Nion, D.; Silva, B.; González, Á.; Barral, M.T. Acidification of mixtures of granite powder and compost for reuse in plant production. Compost Sci. Util. 2016, 24, 1-10. [CrossRef]

56. Lehmann, J.; Rillig, M.C.; Thies, J.; Masiello, C.A.; Hockaday, W.C.; Crowley, D. Biochar effects on soil biota-A review. Soil Biol. Biochem. 2011, 43, 1812-1836. [CrossRef]

57. Abd El-Mageed, T.A.; Semida, W.M.; Taha, R.S.; Rady, M.M. Effect of summer-fall deficit irrigation on morpho-physiological, anatomical responses, fruit yield and water use efficiency of cucumber under salt affected soil. Sci. Hortic. 2018, 237. [CrossRef]

58. Habibi, G. Exogenous salicylic acid alleviates oxidative damage of barley plants under drought stress. Acta Biol. Szeged. 2012, 56, 57-63.

59. Desoky, E.M.; Elrys, A.S.; Mansour, E.; Eid, R.S.M.; Selem, E.; Rady, M.M.; Ali, E.F.; Mersal, G.A.M.; Semida, W.M. Application of biostimulants promotes growth and productivity by fortifying the antioxidant machinery and suppressing oxidative stress in faba bean under various abiotic stresses. Sci. Hortic. 2021, 288, 110340. [CrossRef]

60. Abd El-Mageed, T.A.; El-Sherif, A.M.A.; Ali, M.M.; Abd El-Wahed, M.H. Combined effect of deficit irrigation and potassium fertilizer on physiological response, plant water status and yield of soybean in calcareous soil. Arch. Agron. Soil Sci. 2016, 63, 1-14. [CrossRef]

61. Ghasemi Fahim, M.; Mirzamasoumzadeh, B.; Ahadzadeh, B. Effect of polyethylene glycol on the amount of chlorophyll a, chlorophyll b and total leaf of sugar beet genotypes. J. Bio. Environ. Sci. 2014, 4, 233-237.

62. Semida, W.M.; Abd El-Mageed, T.A.; Mohamed, S.E.; El-Sawah, N.A. Combined effect of deficit irrigation and foliar-applied salicylic acid on physiological responses, yield, and water-use efficiency of onion plants in saline calcareous soil. Arch. Agron. Soil Sci. 2017, 63, 1227-1239. [CrossRef]

63. Semida, W.M.; Abd El-Mageed, T.A.; Abdalla, R.M.; Hemida, K.A.; Howladar, S.M.; Leilah, A.A.A.; Rady, M.O.A. Sequential antioxidants foliar application can alleviate negative consequences of salinity stress in Vicia faba L. Plants 2021, 10, 914. [CrossRef]

64. Semida, W.M.; Abd El-Mageed, T.A.; Abdelkhalik, A.; Hemida, K.A.; Abdurrahman, H.A.; Howladar, S.M.; Leilah, A.A.A.; Rady, M.O.A. Selenium Modulates Antioxidant Activity, Osmoprotectants, and Photosynthetic Efficiency of Onion under Saline Soil Conditions. Agronomy 2021, 11, 855. [CrossRef]

65. Mia, S.; van Groenigen, J.W.; van de Voorde, T.F.J.; Oram, N.J.; Bezemer, T.M.; Mommer, L.; Jeffery, S. Biochar application rate affects biological nitrogen fixation in red clover conditional on potassium availability. Agric. Ecosyst. Environ. 2014, 191, 83-91. [CrossRef]

66. Rondon, M.A.; Lehmann, J.; Ramírez, J.; Hurtado, M. Biological nitrogen fixation by common beans (Phaseolus vulgaris L.) increases with bio-char additions. Biol. Fertil. Soils 2007, 43, 699-708. [CrossRef]

67. Suppadit, T.; Phumkokrak, N.; Poungsuk, P. The Effect of using Quail Litter Biochar on Soybean (Glycine max L. Merr.) Production. Chil. J. Agric. Res. 2012, 72, 244-251. [CrossRef]

68. Yaseen, R.; Shafi, J.; Ahmad, W.; Rana, M.S.; Salim, M.; Qaisrani, S.A. Effect of Deficit Irrigation and Mulch on Soil Physical Properties, Growth and Yield of Maize. Environ. Ecol. Res. 2014, 2, 122-137. [CrossRef]

69. Asai, H.; Samson, B.K.; Stephan, H.M.; Songyikhangsuthor, K.; Homma, K.; Kiyono, Y.; Inoue, Y.; Shiraiwa, T.; Horie, T. Biochar amendment techniques for upland rice production in Northern Laos. 1. Soil physical properties, leaf SPAD and grain yield. Field Crop. Res. 2009, 111, 81-84. [CrossRef] 
70. Van Zwieten, L.; Rose, T.; Herridge, D.; Kimber, S.; Rust, J.; Cowie, A.; Morris, S. Enhanced biological N2 fixation and yield of faba bean (Vicia faba L.) in an acid soil following biochar addition: Dissection of causal mechanisms. Plant Soil 2015, 395, 7-20. [CrossRef]

71. Ghassemi-Golezani, K.; Ghanehpoor, S.; Mohammadi-Nasab, D. Effects of water limitation on growth and grain filling of faba bean cultivars. J. Food Agric. Environ. 2009, 7, 442-447.

72. Ammar, M.H.; Anwar, F.; El-Harty, E.H.; Migdadi, H.M.; Abdel-Khalik, S.M.; Al-Faifi, S.A.; Farooq, M.; Alghamdi, S.S. Physiological and Yield Responses of Faba bean (Vicia faba L.) to Drought Stress in Managed and Open Field Environments. J. Agron. Crop Sci. 2015, 201, 280-287. [CrossRef]

73. Mohamed, I.; El-Meihy, R.; Ali, M.; Chen, F.; Raleve, D. Interactive effects of biochar and micronutrients on faba bean growth, symbiotic performance, and soil properties. J. Plant Nutr. Soil Sci. 2017, 180, 729-738. [CrossRef]

74. Erdem, Y.; Şehirali, S.; Erdem, T.; Kenar, D. Determination of crop water stress index for irrigation scheduling of bean (Phaseolus vulgaris L.). Turkish J. Agric. For. 2006, 30, 195-202. [CrossRef] 